\title{
Studies on the pharmacokinetics and antihypertensive action of verapamil
}

Citation for published version (APA):

Mooij, J. M. V. (1986). Studies on the pharmacokinetics and antihypertensive action of verapamil. [Doctoral Thesis, Maastricht University]. Rijksuniversiteit Limburg.

https://doi.org/10.26481/dis.19860228jm

Document status and date:

Published: 01/01/1986

DOI:

10.26481/dis.19860228jm

Document Version:

Publisher's PDF, also known as Version of record

\section{Please check the document version of this publication:}

- A submitted manuscript is the version of the article upon submission and before peer-review. There can be important differences between the submitted version and the official published version of record.

People interested in the research are advised to contact the author for the final version of the publication, or visit the DOI to the publisher's website.

- The final author version and the galley proof are versions of the publication after peer review.

- The final published version features the final layout of the paper including the volume, issue and page numbers.

Link to publication

\footnotetext{
General rights rights.

- You may freely distribute the URL identifying the publication in the public portal. please follow below link for the End User Agreement:

www.umlib.nl/taverne-license

Take down policy

If you believe that this document breaches copyright please contact us at:

repository@maastrichtuniversity.nl

providing details and we will investigate your claim.
}

Copyright and moral rights for the publications made accessible in the public portal are retained by the authors and/or other copyright owners and it is a condition of accessing publications that users recognise and abide by the legal requirements associated with these

- Users may download and print one copy of any publication from the public portal for the purpose of private study or research.

- You may not further distribute the material or use it for any profit-making activity or commercial gain

If the publication is distributed under the terms of Article $25 \mathrm{fa}$ of the Dutch Copyright Act, indicated by the "Taverne" license above, 
Studies on the Pharmacokinetics

and Antihypertensive Action of Verapamil 
$\because \quad \quad \because$ 


\title{
Studies on the Pharmacokinetics
}

\author{
and \\ Antihypertensive Action \\ of Verapamil
}

\section{Proefschrift}

ter verkrijging van de graad van doctor in de geneeskunde aan de Rijksuniversiteit Limburg te Maastricht, op gezag van de Rector Magnificus, Prof. Dr. F.I.M. Bonke, volgens het besluit van het College van Dekanen, in het openbaar te verdedigen op vrijdag 28 februari 1986 des namiddags om vier uur

door

\section{Jacob Manuel Victor Mooij}

geboren te Gramsbergen

B.V. Leiter-Nypels - Maastricht 1986 
Promotor: Prof. Dr. K.H. Rahn

Co-promotor: Prof. Dr. H.A.J. Struyker Boudier

Referenten: Prof. Dr. K.D. Bock

Prof. Dr. F.W.J. Gribnau

Prof. Dr. H.J.J. Wellens

This study was performed in the Laboratory of Clinical Pharmacology of the University of Limburg, Maastricht, The Netherlands, and financially supported by the Dutch Kidney Foundation (Nierstichting Nederland). 


\section{Contents}

Chapter 1

Chapter 2

Chapter 3

Chapter 4

Chapter 5

Chapter 6

Samenvatting

Curriculum vitae

Dankwoord
Introduction

Pharmacokinetics of verapamil in patients with renal failure

Influence of prolonged submaximal exercise on the pharmacokinetics of verapamil in man

A comparison of the effects of verapamil and propranolol on submaximal exercise tolerance in patients with essential hypertension

General discussion and summary 


\section{Chapter I}

Introduction 


\section{A. General introduction}

Calcium ions play an important role in many biological processes, like enzymatic reactions, stimulation of cells, secretion, haemostatis (ANGHLLRI and TUfFet-ANGhileri 1982). They also have an important function in the myocardium and in the vascular smooth muscle cells. During the plateau phase of the action potential in the myocardium and during excitation of smooth muscle cells, there is a slow inward current of calcium ions into the cells through the so-called slow channels or calcium channels in the cell membrane (fig. 1). These slow channels are 100 times more selective for calcium than for sodium (Reuter and Scholz 1977). Because of this process, there is a marked rise of calcium in the cytoplasma. In the vascular smooth muscle cells this calcium binds to a protein, the so-called calmodulin, in the cell. This calciumcalmodulin complex activates the enzyme myosine-kinase, which phosphorylates the light chains of myosine. This permits myosine to bind with actine, leading to contraction of the smooth muscle cell (Silver and STULL 1982).

Since the pioneering work of FlECKENSTEIN about 20 years ago, it is known that there are some organic compounds which produce a selective blockade of the slow inward current of calcium into the cell (FLECKENSTEIN 1971). Characteristic for this group of drugs is that they diminish contractile force without a major change in the action potential. In other words, they inhibit excitation-contraction coupling (FLECKENSTEIN 1964).

The first drug found to have a calcium entry inhibiting effect was verapamil (Fleckenstein 1964 and Fleckenstein et al. 1967).

Later were found gallopamil, nifedipine, nitrendipine, nisoldipine, nicardipine, niludipine, nimodipine, felodipine, diltiazem (NAvLler and Horowitz 1983). These compounds strongly differ in structure (fig. 2). Verapamil and gallopamil are derivates of papaverine; nifedipine, nitrendipine, nisoldipine, nicardipine, niludipine, nimodipine and felodipine belong to the group of dihydropyridines. Diltiazem is a benzothiazepine derivate.

The mode of action of these drugs is probably such that they bind to receptors which are functionally linked to the calcium channels. There are found at least two and probably three distinct receptors for the calcium antagonists: one for the dihydropyridines, one for the verapamil-like drugs, and possibly one for diltiazem (SNIJDER and REynoLds 1985). There are, however, some links between these receptors. Verapamil and related agents are especially effective in blocking calcium channels which are opened and closed frequent- 

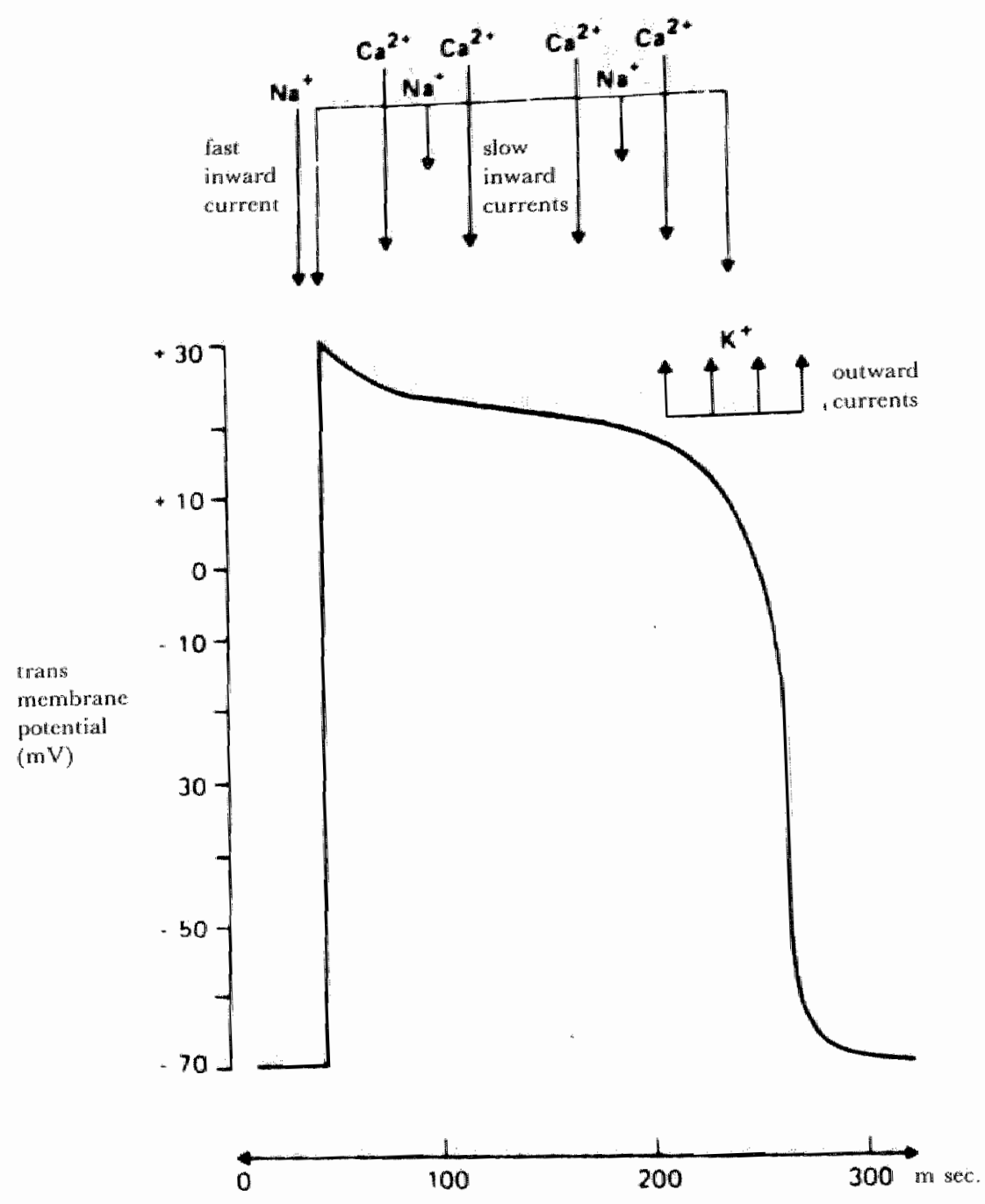

Fig. 1. Ion fluxes associated with the myocardial action potential. (according to Nayler and Horowitz 1983) 

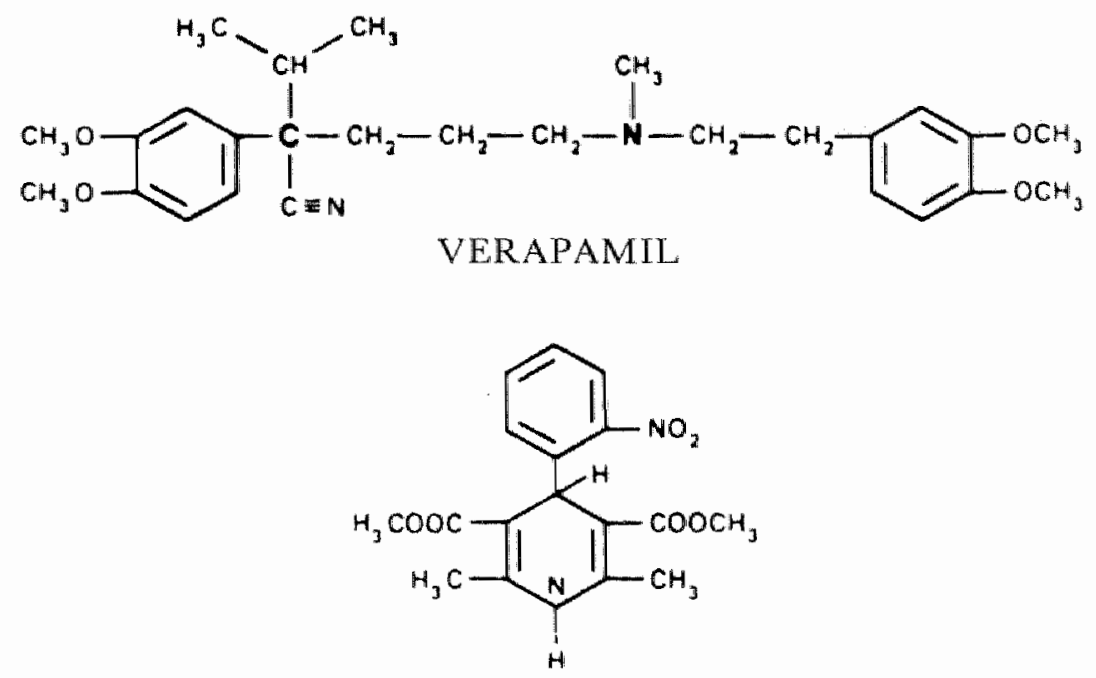

NIFEDIPINE

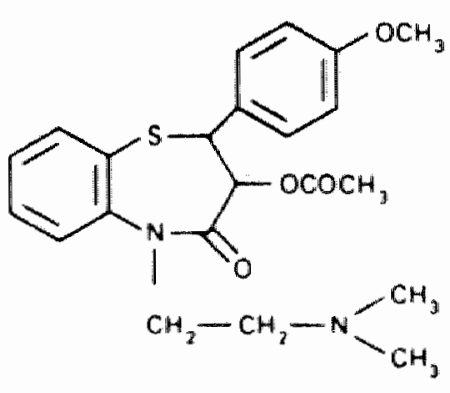

DILTIAZEM

Fig. 2. Structures of verapamil, nifedipine and diltiazem. 
ly. High concentrations of the calcium antagonists also inhibit the effects of alpha-adrenergic agonists on calcium entry into the cell and the by this process triggered release of calcium from intracellular stores (BRODIE 1984, VAN ZWIETEN 1984).

Compounds that inhibit the entry of calcium into the cells, have in principal very different functions. They act on the atrioventricular conduction system of the heart, the myocardial cells, the vascular smooth muscle cells (coronary, renal, mesenterial arteries), smooth muscle cells in the respiratory tree and the gastrointestinal tract, pancreatic beta cells and other secretory cells, mast cells and thrombocytes (FLAIM and Zecis 1982). There is, however, a kind of specificity in the action of these drugs (BRAUNwALD 1982). Verapamil especially affects the smooth muscle cells of the vascular system, but also, to a less degree, of the gastrointestinal tract. In addition, it influences the myocardial cells and especially the cells of the sinus node and the cells of the atrioventricular conduction system (LINDEN and BROOKER 1980). Nifedipine especially acts on the vascular smooth muscle cells, e.g. of the coronary arteries, and much less on the myocardial cells.

Diltiazem dilates the coronary system very effectively. The venous system is much less sensitive for the action of the calcium antagonists, although venous pooling can be seen with some drugs of this group.

The principal haemodynamic abnormality in essential hypertension is an increase in the peripheral vascular resistance (LUND-JOHANSEN 1980). Therefore, because of their effect on the cardiovascular system, the calcium antagonists can also be useful in the treatment of hypertension.

In this study one of the calcium antagonists, namely verapamil, will be discussed more extensively, especially with regard to its antihypertensive properties.

\section{B. History}

In 1962 HAAS and HAERTFELDER published the first animal experiments with a new drug:

$\alpha$-Isopropyl- $\alpha$-[(N-methyl- $\mathrm{N}$-homoveratryl)- $\gamma$-amino-propyl]-3,4-dimethoxyphenylacetonitril (D 365), later called verapamil. The compound was developed as a coronary vasodilating agent in the Knoll Laboratories in Germany. It appeared to have beside a vasodilating effect a cardiodepressive and 
hypotensive action. In 1963 the company asked Professor FLEckenstein to have a look on this drug because of these unexplained side effects. Soon it turned out that the drug mimicked the cardiac effects of simple calcium withdrawal (FLECKENSTEIN 1964). Verapamil inhibited contractibility without a change in action potential (fig. 3). At this time, the drug was already frequently used for patients with coronary heart disease. Soon, other important qualities of verapamil were demonstrated. It was shown that the drug also had a negative chronotropic influence on the atrioventricular conduction as well as an antiarrhythmic effect (BENDER et al. 1966, BENDER 1968).

Furthermore, the antihypertensive action of verapamil was tested in hypertensive patients (Brittinger et al. 1969, Bender 1970).

Nowadays, verapamil is widely used for several clinical indications including supraventricular tachycardia, atrial flutter and fibrillation, angina pectoris at rest and at effort, hypertrophic cardiomyopathy, pulmonary hypertension, and systemic hypertension (OpIE 1984).

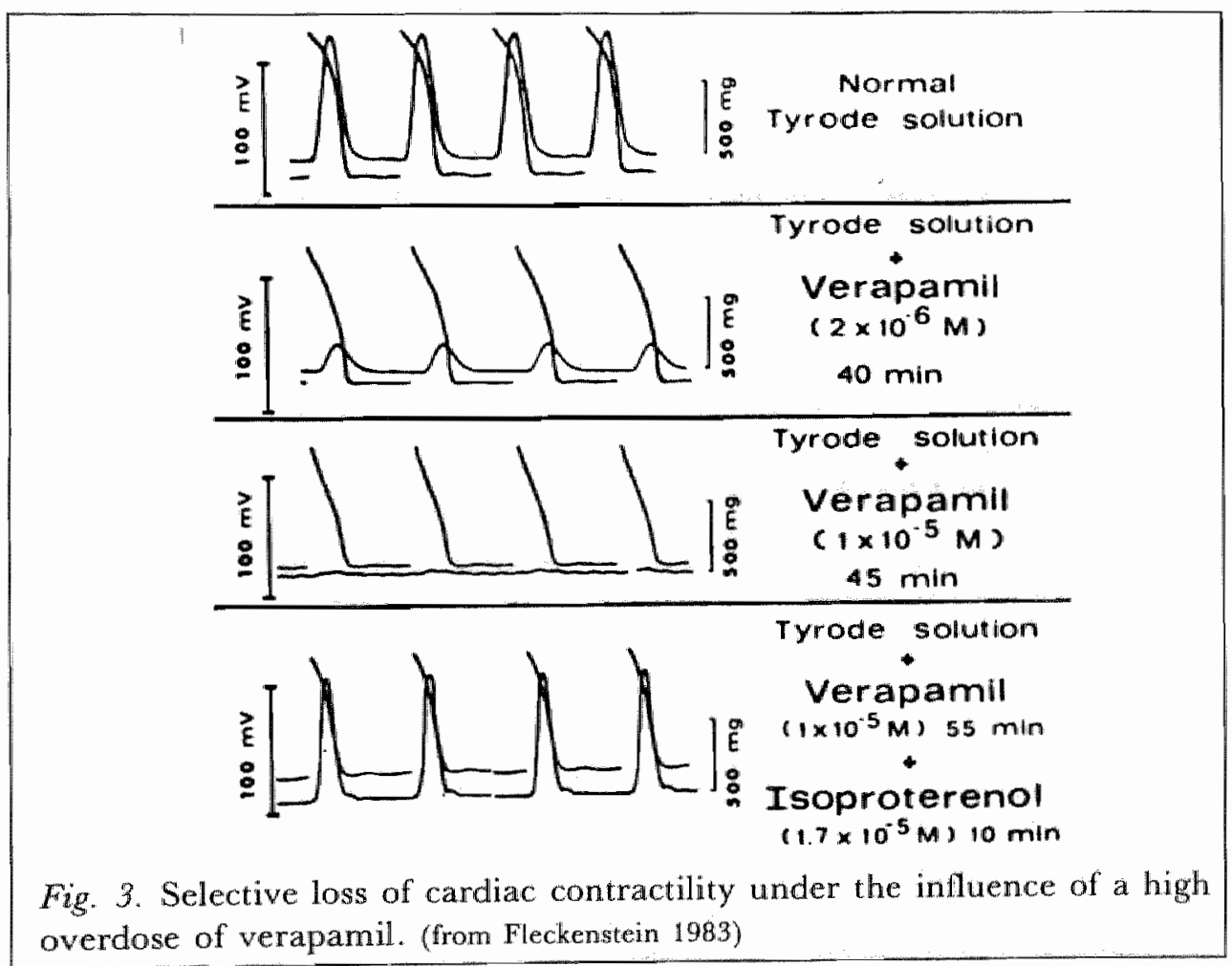


The drug has also been given for preservation of renal function after ischaemia (WIDENER et al. 1984. Ishigam et al. 1984) and during treatment with cytostatic agents (Tsuruo et al. 1982).

\section{c. Pharmacokinetics}

The pharmacokinetics of verapamil in normal subjects have been studied extensively (Schomerus et al. 1976, Erchrlbaum et al. 1979, Kates 1983, Hamann et al. 1984). Verapamil is rapidly and completely absorbed following oral administration (SCHOMERUS et al. 1976). During the first pass through the liver a great percentage of the drug is already metabolized (extraction fraction is 0.79). The biological availability after oral administration is therefore only 10 to $20 \%$ (Erchel.baum et al. 1979, Mc Altister et al. 1982). In patients with liver disease the bioavailability after oral administration is increased (Somocy et al. 1981). There is also a great inter-individual variability in the biological availability (EICHELBAum and Somogyr 1984). The peak level of verapamil after oral administration is reached at 1,5 to 2 hours (Mc Allister et al. 1982). In plasma, verapamil is bound to plasma proteins for $90 \%$. For some effects of verapamil it has been demonstrated that there is a direct correlation with the concentration of free, unbound verapamil (Dominic et al. 1981). Therefore, shifts in the protein binding may cause an unwanted rise of the concentration of free, effective verapamil. Verapamil is widely distributed in the body with a volume of distribution of 3.5 to $61 / \mathrm{kg}$ body weight.

The elimination of verapamil mainly occurs by metabolism in the liver. The most important metabolite of verapamil is norverapamil. As compared with verapamil norverapamil is lacking a methylgroup. Is has still a biological activity of $20 \%$ of that of the parent drug (NEUGEBauer 1978). The elimination half-life of verapamil is 3 to 7 hours. Prolongation of the half-life has been demonstrated during chronic oral administration (Schwartz et al. 1982a and TARTAGLIONE et al. 1983). The disposition kinetics after intravenous administration follow an open two-compartment model according to Dominic et al. (1981). Other authors (FrEEDMAN et al. 1981) conclude that a three-compartment model is more appropriate. Eichelbaum et al. (1984) demonstrated a stereo-selective elimination of the more active $L$-isomer of verapamil by the liver. As a consequence the plasma verapamil concentration required for a given increase of $\mathrm{AV}$-conduction time was 2-3 times higher after an oral dose than after intravenous administration. Only $3 \%$ (EIGHeleaum et al. 1979) and 10\% (Korke et al. 1979) of the administered verapamil appears in the urine in unchanged form. 


\section{Acute haemodynamic effects of verapamil}

The first clinical studies about the hypotensive action of verapamil in hypertensive patients were performed with intravenous administration of the drug (BRITTINGER et al. 1969, BENDER 1970). 5 mg of verapamil intravenously resulted in a fall of the systolic and diastolic blood pressure of 10 to $15 \%$. The hypotensive effect was greater when the initial blood pressure was higher.

The haemodynamic effects caused by bolus intravenous administration of verapamil were studied by VINCENZI et al. (1976). There was an increase of the heart rate by $14 \%$ and of the cardiac index by $24 \%$. The peripheral vascular resistance decreased by $33 \%$, and the mean arterial pressure by $15 \%$. There was also a decrease of the mean pulmonary pressure by $11 \%$.

The parenteral administration of verapamil has proved effective in hypertensive crises (BENDER 1980). Because of the short duration of this effect of verapamil after bolus injection, sllow infusion has been applied (Lederballe Pedersen 1978). The increase in heart rate is a result of reflex sympathetic stimulation following vasodilation. Because of its effect on the atrioventricular node, the injection should be given very cautiously, and under strict electrocardiographic monitoring (HEIDLAND et al. 1982).

\section{E. Long-term haemodynamic effects of verapamil}

Numerous studies have established the hypotensive effect of verapamil in patients with hypertension (Lewis et al. 1978, Midtbo et al. 1980, Anavekar et al. 1981, Gould et al. 1982, Wicker Et Al. 1984, Wigler et al. 1984, Doyle 1985). Because of the low bioavailability after oral administration, verapamil has to be given in much higher doses orally than the same drug intravenously. In hypertensive patients a decrease of the systolic and diastolic pressure was seen mostly by $10 \%$ after treatment with $80 \mathrm{mg} \mathrm{t}$.i.d.. In some patients this dose is insufficient, and has to be enhanced to $160 \mathrm{mg}$ t.i.d. By means of continuous monitoring of intra-arterial blood pressure, Gould et al. (1982) found a consistent reduction of blood pressure over 24 hours, particularly during the day. Heart rate was similarly reduced (fig. 4). There were no signs of postural hypotension.

As with all the calcium antagonists, the antihypertensive effect is pronounced when the pretreatment level of the blood pressure is high (BUEHLER et 


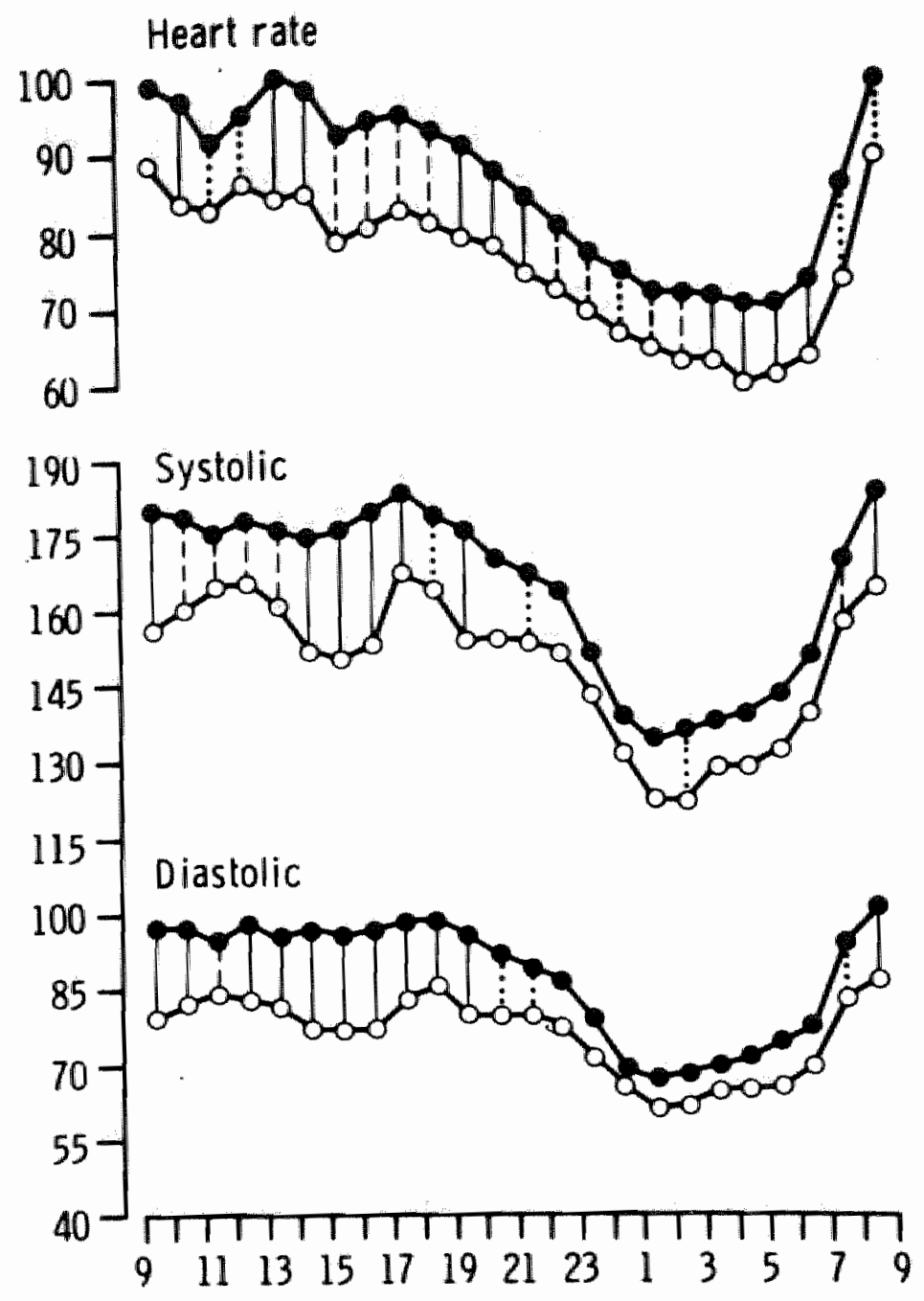

Fig. 4. Circadian curves derived from hourly mean values of heart rate, systolic and diastolic blood pressure before $(\bullet)$ and after $(0)$ verapamil. $(p<0.05 \ldots \ldots \ldots ; p<0.01 \ldots . . ; p<0.001 \ldots)$.

(from Gould et al 1982) 
al. 1982, MUELLER et al. 1984). In normotensive patients verapamil has practically no effect (BUEHLER et al. 1982).

According to BUEHLER et al. (1982) there is also a strong direct relationship between the age of the hypertensive patient and the antihypertensive effect. There is an indirect correlation between the pretreatment plasma renin activity and the antihypertensive effect of verapamil (BUEHLer et al. 1982).

The haemodynamic actions of long-term use of verapamil have been studied by Lund-JoHANSEN (1984). Treatment with verapamil 120-240 mg daily resulted in a $10 \%$ decrease of systolic and diastolic blood pressure at rest, slightly less during exercise. The blood pressure reduction was associated with a reduction in total peripheral resistance. The heart rate was unchanged at rest supine, but decreased by about $8 \%$ at rest in sitting position and during exercise. The stroke volume was increased by $11 \%$ at rest and less during exercise. The cardiac index was unchanged.

This haemodynamic profile of verapamil is quite different from the effect induced by beta-blockers. A great advantage of verapamil in contrast to nifedipine and the classical vasodilators is that with long-term use it does not cause reflex tachycardia. The main reason for this effect is probably the negative influence of this drug on the sinus node (Lewrs 1980). However, in dogs also a direct inhibitory effect of verapamil on baroreceptors has been found (HEEsch et al. 1983).

\section{F. Renal effects of verapamil}

Clearance studies with inulin have shown that intravenous infusion of verapamil has no significant effect on glomerular filtration rate in normal subjects and hypertensive patients with inflammatory kidney disease. An increase of para-aminohippuric acid clearance by $14 \%$ was observed in patients with essential hypertension and impaired effective renal plasma flow (HEIDLAND et al. 1982). Renal blood flow remained essentially unchanged during oral verapamil (de Leeuw et al. 1981). Semplicini et al. (1982), Sørensen et al. (1985) and ZANCHETTI and LEONETTI (1985) found no change in renal plasma flow and glomerular filtration rate during oral treatment with verapamil despite the fall in blood pressure. Leonetrr et al. (1980) and Wroler et al. (1984) did not find a deterioration of renal function during chronic treatment with verapamil. 
Chronic administration of verapamil did not cause sodium and water retention (Muiesan et al. 1982, ZANCHETTI and LeONETT 1985). The body weight remained constant or decreased slightly (LEwIs et al. 1979).

The decrease of blood pressure during chronic verapamil administration without renal sodium and water retention is very remarkable for a vasodilating agent. Mo Corex et al. (1979) gave an intrarenal infusion of verapamil in dogs. This resulted in renal vasodilation, diuresis and natriuresis. The effects on tubular sodium reabsorption were independent from changes of glomerular filtration rate and renal plasma flow, possibly because of an effect of the calcium antagonist on the tubular cells. Similar results are found by DiETz et al. (1983). SøRENSEN et al. (1985) found no effect of verapamil on renal handling of sodium and potassium in humans. The free water clearance was not influenced, too. However, a small but significant decrease in cumulative sodium balance has been found during 10 days treatment with verapamil (DE LEeUW and BIRKENHAEGER 1984).

\section{G. Hormonal effects of verapamil}

After intravenous injection of verapamil an increase of plasma renin activity has been found (MAcometschnigG et al. 1984). However, plasma noradrenaline and adrenaline levels were unchanged after acute administration of this drug (LEONETTr et al. 1982). Reduction of arterial pressure during chronic verapamil administration did not result in an increased renin activity (De Leeuw et al. 1981, Leonetti et al. 1980, Muiesan et al. 1981, Anavekar. et al. 1981). Plasma aldosterone and total catecholamine levels also remained constant (DE Leeuw et al. 1981, Muresan et al. 1981 and Stern et al. 1984). SǿRENSEN et al. (1985) found no change of plasma levels of plasma angiotensin II, aldosterone and arginine vasopressin during treatment with verapamil.

The reason for these effects could be an inhibitory influence of calcium blockade on endocrine cells (Millar and Struthers 1984). Verapamil also inhibits the angiotensin II and potassium induced increased aldosterone secretion in isolated rat and canine glomerulosa cells (FAKUnding et al. 1980). Inhibitory effects on hormone release by verapamil have been described for the adenohypophysis, endocrine pancreas and adrenal cortex. It seems unlikely that verapamil has a clinically significant effect on glucose tolerance in normal subjects (SEMPLE et al. 1983). 


\section{H. Interactions with other drugs}

\section{Beta-adrenoceptor blocking agents.}

Calcium antagonists are potential negative inotropic agents (OpIE 1984). Diltiazem is the agent with least direct myocardial depression while in the case of nifedipine the negative inotropic effect is counteracted by the potent peripheral vasodilation and reflex sympathetic stimulation. However, with verapamil special care is required with regard to this effect because of its influence on nodal tissue. This is especially the case in the presence of preexisting beta-adrenergic blockade. The bolus injection of verapamil in parients treated with beta-blockers is very dangerous because of the additive depressive effects of these drugs and verapamil on cardiac tissue (OPIE 1984). Therefore, the intravenous administration of verapamil together with beta-blocking agents is contra-indicated.

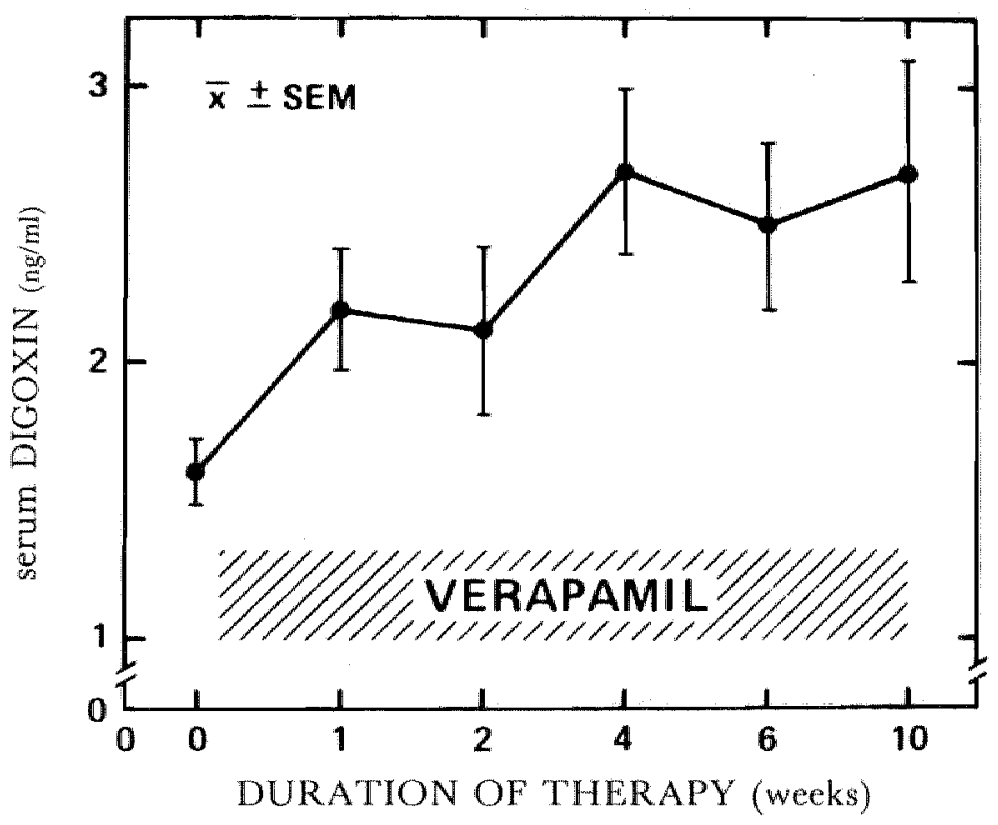

Fig. 5 Influence of verapamil (160 - 480 daily) on serum digoxin levels.

(from Schwartz et al. 1982b) 


\section{Digoxin}

An important phamacokinetic interaction between verapamil and digoxin has been described by KLein et al. (1980) and Schwartz et al. (1982b). These authors found that without verapamil the mean digoxin level in the patients while using this drug was $1.6 \mathrm{ng} / \mathrm{ml}$. With verapamil 160 to $480 \mathrm{mg}$ daily the mean plasma level of digoxin raised without alteration of the dose to $2.7 \mathrm{ng} / \mathrm{ml}$ (fig. 5). In some patients obviously toxic blood levels of digoxin were found. Verapamil reduces both renal and extra-renal clearance of digoxin (PEDERSEN et al. 1981).

\section{Side effects of verapamil}

The most important side effect of verapamil is a prolongation of the atrioventricullar conduction time. This can be especially dangerous in patients with pre-existing atrioventricular conduction disturbance or with beta-adrenergic blockade treatment (OpIE 1984). Otherwise when cautiously used verapamil induces relatively few side effects. The most frequent adverse reaction is constipation (DOYLE 1985). Other side effects are flushing and headache. In contrast to nifedipine palpitations and local edema are rarely encountered. Orthostatic hypotension does not occur. In only $1 \%$ of the patients using verapamil the drug has to be discontinued because of adverse reactions (RAHN 1984).

\section{J. Concluding remarks}

Calcium entry blocking agents in general and verapamil in particular are now very valuable drugs for the treatment of hypertension (Dorle 1985). The effects. of these agents are apparently comparable with the responses to beta-blockers and diuretics. Possibly calcium entry blockers now may represent the first-line therapy for a big group of hypertensive patients. This is especially the case for patients with bronchospastic disease and older patients (BUEHLER et al. 1982). A disadvantage of verapamil and nifedipine is the relatively short half-life. This results in a three times per day dosage schedule. The newer representatives of the calcium antagonists, e.g. nitrendipine, have a longer elimination half-life.

In conclusion, this group of drugs has many advantages and is a valuable tool for the treatment of different forms of hypertension. 


\section{к. Purposes of the study}

Although there is already much known about the calcium antagonists in general, and about verapamil in particular, there are no or very few data available concerning some important aspects of the antihypertensive action of verapamil. Therefore, we decided to study the following aspects:

1. Pharmacokinetics of verapamil in renal failure (chapter 2).

2. Drug interactions with verapamil (chapter 3).

3. Influence of prolonged submaximal exercise on the pharmacokinetics of verapamil in man (chapter 4 ).

4. A comparison of the effects of verapamil and propranolol on submaximal exercise tolerance in patients with essential hypertension (chapter 5).

Finally, a general discussion and summary will be given. 


\section{References}

Anatekar SN, Christophidis $\mathrm{N}$, Louis WJ, Doyle AE (1981) Verapamil in the treatment of bypertension. I of Cardiovasc Pharmacology 3: 287-292

Anghiler $L$ L and Tufet-Anghleri $A M(1982)$ The role of calcium in biological systems. CRC presis, Boca Raton (FI) DSA

Bender $F$, Kojma $N$, Reploh $H$, Oelmann $G$ (1966) Behandlung tachykarder Rhythmusstoerungen des Herzens durch Beta-Rezeptorenblockade des Atrioventrikulargewebes. Med Welt $17: 1120-1123$

Bender $\mathrm{F}$ (1968) Die medikamentoese Behandlung won Herwhytmusstoenungen. Therapiewoche 40: $1803-1809$

Bender F (1970) Die Behandlung der tachykarden Arrhytmieen und der arteriellen Hypertonie mit Isopin. Arzneimittel-Forschung 20:1310-1316.

Bender F (1980) Acute hypertensive crises. Clinical and Investigative Medicine 3: 169-174.

Braunwald $\mathrm{E}$ (1982) Mechanism of action of calcium-channel blocking agenis. New Engl $J$ of Med 307: $1618-1627$

Brittinger WD, Strauch $M$, Huber $W$, Koch WD, v. Henning GE, Wittenmeier KW, Twittenhoff WD (1969) Iproveratril als Antihypertonicum bei krisenhafter renaler Hypertonie. Desch med Wschr 94: $945-948$

Brodic MJ (1984) Clinal pharmacology of calcium antagonists. In: Calcium antagonists and the trestment of hypertension: 3-12. Ed. : Reid JL and Pickup AJ. Royal Society of Medicine, London.

Buehler FR, Hulthen UL, Kiowski W, Mueller FB, Bolli P (1982) The place of the calcium antagonist verapamil in antihypertensive therapy. J of Cardiovascular Pharmacol 4: S350-S357

Dietz JR, Davis JO, Freeman RH. Villarreal D, Echtenkamp SF (1983) Effects of intrarenal infusion of calcium entry blockers in araesthetized dogs. Hypertension 5: 482-483.

Dominic JA, Bourne DWA. Tan TG, Kirsten EB, MCAlhister RG JW (1981) The pharmacology of verapamil. III. Phamacokinetics in normal subjects after intravenous drug administration. I of Cardiovascular Pharmacol 3: 25-38.

Doyle AE (1985) Galcium antagonists. In: Calcium and calcium-antagonists in hypertension. Proceedings of the Satellite Symposium to the 2nd European Meeting on Hypertension, Milan, in press.

Eichelbaum M, Ende M, Remberg G. Sehomerus M, Dengler HJ (1979) The metabolism of DL-("C)-veraparnil in man. Drug Metab Dispos 7: 145-148

Eichelbaum M, Somogyi A, von Unruh GE, Dengler HJ (1981) Simultaneous determination of the intravenous and oral pharmacokinetic parameters of DL-verapamil using stable isolopelabelled verapamil. Eur I Clin Pharmacol 19:133-137.

Eichelbaum M, Mikus $G$, Vogelgesang B (1984) Pharmacokinetics of (t)-, (-) - and ( verapamill after intravenous rdministration. $\mathrm{Br} J$ of Clin thamacol $17: 453-458$ 
Eichelbawm M, Somogyi A (1984) Inter- and intra-subjects vanation in the first-pass elimination of highly cleared drugs during chronic dosing studies with deuterated verapamil. Eur J of Clin Phärmacol 26: $47-53$.

Fakunding JL, Catt KJ (1980) Dependence of aldosterone stimulation in adrenal glomerulosa cells on calcium uptake: effects of lanthanum and verapamil. Endocrinology 107:1345-1353

Flaim SF, Zelis R (1982) Calcium blockers. Mechanisms of action and clinical applications. Urban and Schwarzenberg, Baltimore (USA)

Fleckenstein A (1964) Die Bedeutung der energiereichen. Phosphate fuer Kontraktilitaet und Tonus des Myokards. Verh Disch Ges Inn Med 70: 81-99

Fleckenstein A, Kammermeier H, Doering HJ, Freund HJ (1967) Zum Wirkungsmechanismus neuartiger Koronardilatatoren mit gleichzeitig Sauerstoff-einsparenden Myokard-Effekten, Prenylamin und Iproveratril. Z Kreislaufforsch 56: 716-744, 839-859

Fleckenstein A (1971) Specific inhibitors and promotors of calcium action in the excitationcontraction coupling of heart muscle and their role in the production or prevention of myocardial lesions. In: Calcium and the heart: 135-188 Edited by Harris P, Opie L, Academic Press, New York

Fleckenstein $A$ (1983) History of Calcium Antagonists. Circulation Research 52 Suppl I: 3-16

Freedman SB, Richmond DR, Ashley JJ, Kelly DT (1981) Verapamil kinetics in normal subjects and patients with coronary artery spasm. Clin Pharm and Ther 30: 644-652

Gloor $\mathrm{HO}$, Urthaler $\mathrm{F}$ (1983) Differential effect of verapamil isomers on sinus node and $\mathrm{AV}$ junctional region. Am J Physiology 244: H80-H88

Gould BA, Mann S, Kieso H, Bala Subramanian V, Raftery EB (1982) The 24-hour ambulatory blood pressure profile with verapamil. Circulation $65: 22-27$

Haas $H$, Haertfelder $G$ (1962) $\alpha$-Isopropyl- $\alpha$ - [(N-methyl-N-homoveratryl)- $\gamma$-amino-propyl]-3, 4-dimethoxyphenylacetonitril, eine Substanz mit coronargefaesserweiternden Eigenschaften. Arzneimittel-Forschung 12: $549-558$

Hamann SR, Blouin RA, McAllister Jr. RG (1984) Clinical pharmacokinetics of verapamil. Clinical Pharmacokinetics 9: 26-41

Hessch CM, Miller BM. Thames MD, Abboud FM (1983) Effects of calcium channel blockers on isolated carotid baroreceptors and baroreflex. Am J Physiol 245: H653-H661

Heidland A, Heidbreder $\mathbb{E}$, Hoerl WH, Schaefer R (1982) Callcium antagonists in the treatment of hypertersion. Contr Nephrol 33: 254-269

Ishigami M, Magnusson MO, Stowe NT, Straffon RA (1984) The salutary effect of verapamil and d-propranolol in ischemically damaged kidneys. Transplantation Proceedings 16:40-43

Kates RE (1983) Calcium antagonist: pharmacokinetic properties. Drugs 25: 113-124

Klein HO, Lang R, Weiss E, Desegni E, Kaplinsky E (1980) Verapamil digoxin inceraction. New Engl J of Med 303: 160

Koike Y, Shimamura K, Shudo I, Saito H (1979) Pharmacokinetics of verapamil in man. Res Commun Chem Pathol Pharmacol 24: 37-47

Lederballe Pedersen O (1978) Does verapamil have a clinically significant antihypertensive effect? Eur J Clin Pharmacol 13: 21-24 
de Leeuw PW, Smout AJPM, Willemse PJ, Birkenhaeger WH (1981) Effecis ar verapamil in hypertentive patients. In: Calcium antagonism in cardiowascular therapy: experience with werapamil. Proceedings of the International Symposium on calcium antagonism in cardiovas cular therapy, Florence, 1980: 233 237. Editors: Zancheti A and Krikler DM. Excerpta. Medica, Amsterdam-Oxford-Princeton.

de Lecuw PW, Birkenhaeger WH (1984) Effects of werapamil in bypertensive patients. Acta Med Scand Suppl 681: 125-128.

Leoneti G, Sala C, Bianchini $C$, Terzoli $L$, Zanchetu A (1980) Antihypertensive and renal effects of orally administered verapamil. Eur J Clin Pharmacol 18:375-382

Leonetri $G$, Cuspidi $C$, Sampieri $L$, Terzoli $L$, Zanchetti A (1982) Comparison of cardiovascular, renal, and humoral effects of acute administration of two calcium channel blockers in normotenisive and hypertensive subjects. $J$ of Cardiovascular Pharmacology 4: $\$ 319-\$ 324$.

Lewis GRJ, Morlley KD, Lewis BM, Bones $\mathrm{PJ}$ (1978) The treatment of hypertension with verapamil. New Zealand Medical Journal 87: 351-354

Lewis GRJ. Morely KD, Maslowski A, Bones PJ (1979) Verapamil in the management of hypertensiwe patients. Aust NZJ Med 9: 62-64

Lewis GRJ (1980) Verapamil in the management of chronic hypertension. Clin Invest Med 3 . 175.177

Linden $J$, Brooker $G$ (1980) The influence of resting membrane potential on the effect of verapamil on atria. $J$ Moll Cell Cardiol $12: 325-331$ Lund-Johansen P (1980) State of the art review. Haemodynamics in essential hypertension.
Clin Sci 59: 343s-354s

Lund-Johansen P (1984) Hemodynamic effects of verapamil in essential hypertension at rest and during exercise. Acta Medica Scand Suppl 681: 109-115

Magometschnigg D, Hoertnagl $\mathrm{H}$, Rameis $\mathrm{H}$ (1984) Diltiazem and verapamil: Functional anthagonism of exogenous noradrenaline and angiotensin II in man. Eur J of Clin Pharmacol 26 :

McAllister RG, Kirsten EB (1982) The pharmacology of verapamil. IV. Kinetic and dynamic effects after single intravenous and oral doses. Clin Pharmacol Ther 31:418-426

McGrorey HL, Berl T, de Torrente A, Schrier RW (1979) Efect on calcium (Ca) transpon inhibitors on renal hemodynamics and electrolyte excretion in the dogr. Kidncy Invernational
16: 857

Midtbo K. Hals MD (1980) Verapamil in the treatment of hypertension. Current Therapeutic
Rescarch $27: 830-838$

Millar JA, Stuthers AD (1984) Calcium antagonists and thormone release. Clin Sci 66: 249-255

Muiesan G, Agabili-Rosei E, Alicandri C, Beschi M, Castellano M, Corea L, Fariello R Romanelli $G$. Pasini $G$, Platto $L$ (1981) Influence of verapamil on catecholamines, renin and aldosterone in essenial hypertensive patients. In: Calcium Antagonism in cardiovascular therapy: experience with verapamil. Procedings of the International Symposium on calcium antagonism in cardiovascular therapy, Florence, 1980: 238-249. Ed. Zanchett A and Krikler 
Muiesan G, Agabiti-Rosei E, Castellano M, Alicandri GL, Conea L, Fariello R, Beschi M, Romanelli $\mathrm{G}$ (1982) Antihypertensive and humoral effects of verapamil and nifedipine in essential hypertension. J of Cardiovasc Pharmacology 4: S325-\$329.

Mueller FB, Bolli P, Erne P, Kiowski W, Buehler FR (1984) Use of calcium antagonists as monotherapy in the management of hypertension. The American Journal of Medicine 77 (2B): $11-15$

Nayler WG and Horowitz JD (1983) Calcium antagonists: a new class of drugs. Pharmac Ther 20: $203-262$

Neugebauer G (1978) Comparative cardiovascular actions of verapamil and its major metabolites in the anaesthetised dog. Cardiovasc Res 12:247-254

Opie LH (1980) Calcium antagonists. Lancet i: 806-809

Opie LH (1984) Calcium antagonists. Mechanisms, therapeutic indications and reserwations: a review. Quarterly Journal of Medicine New Series LIII, 209: 1 16

Pedersen KE, Dorph-Pedersen A, Hvidt S, Klitgaard NA, Nielsen-Kudsk F (1981) Digoxinverapamil interactions. Clin Pharmacol and Ther $30: 311.316$

Rahn KH (1984) Calciumantagonisten in der Hochdrucktherapie. Dtsch med Wschr 109: $933-934$

Reuter H, Scholz $\mathrm{H}(1977)$ A study of the ion selectivity and the kinetic properties of the calcium dependent slow inward current in mammalian cardiac muscle. J Physiol 264: 17-4.7

Schomerus M, Spiegelhalder B, Stieren B, Eichelbaum M (1976) Physiological disposition of verapamil in man. Cardiovasc Res 10: 605-612

Schwartz JB, Keefe DL, Kirsten E, Kates RE, Harrison DC (1982a) Prolongation of verapamil elimination kinetics during chronic oral administration. American Heart Journal 104" 198-203

Schwartz JB, Keefe DL, Kates RE, Kirsten E, Harrison DC (1982b) Acute and chronic pharmacodynamic interaction of verapamil and digoxin in atrial fibrillation. Circulation 65 : $11163-1170$

Semple CG, Thomson JA, Forbes CD, Beastall GH, Lorimer AR (1983) Oral verapamil has no effect on glucose tolerance in non-diabetics. Clin Sc 54: $25 \mathrm{p}-26 \mathrm{p}$

Semplicini $A$, Pessina $A$, Rossi G, Padrini R, Taglaticro $R$, Quintarelli $G$, Ferrari M, Dal Pallu $C$ (1982) Plasma levels of verapamil and its effects on blood pressure, body fluid vollumes and renal function in hypertensive patients. Int J Clin Pharm Res 11, Suppl 1:81-86

Silver PJ, Stull JT (1982) The role of calcium in the contraction of vascular smooth muscle. In: Calcium blockers. Mechamism of action and clinical applications. Edited by $\mathbb{F l a m} \mathrm{SF}$ and Zelis R. Urban and Schwarzenberg, Baltimore (USA)

Singh BN, Ell rodi G, Peter CT (1978) Verapanil: a review of its pharmacologieal propertics and therapeutic usc. Drugs 15: 169-197

Snijder SH and Reynolds IJ (1985) Calcium-antagonist drugs: receptor interactions that clarity therapeutic effects. New Engl J Med 313: $995-1002$ 


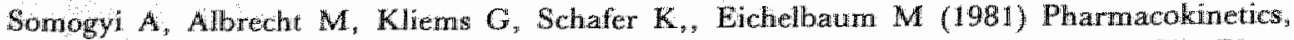
bioavialability and $\mathrm{ECG}$ response of verapamil in patients with liver cirhosis. Br J Clin Pharmacol 12: $51-60$

Sorensen SS, Thomsen OD, Danielsen H, Pedersen EB (1985) Effect of verapamil on renal plasma flow, glomerular filtration rate and plasma angiotensin 11 , aldosterone and arginine vasopressin in essential hypertension Eur J Clin Pharmacol 29: 257-261.

Stein DT, Lowenthal DT, Stephen Porter R, Falkner B, Bravo EL, Hare ThW (1984) Effects: of nifedipine and werapamil on isometric and dynamic exercise in normal subjects. American Jounal of Cardiology 54: $386-389$

Tartaglione T, Pieper J, Lopez L, Mehta J (1983) Pharmacokinetics of verapamil and norverapamil during long-term oral therapy. Reserach Comm in Chem Path and Pharmacol 40: $15-27$

Tsuruo T, Lida $H$, Tsukagoshi S, Sakurai $Y$ (1982) Increased accumulation of vincristine and adriamycin in drug resistant P38 tumor cells following incubation with calcium ancagonists and calmodulin inhibitors. Cancer Research 42: 4730-4733

Vincenzi M, Allegri P, Gabaldo S, Maiolino P, Ometto R (1976) Hemodynamic effects caused by $i$.v. administration of werapamil in healthy subjects. Arzneimittel-Forschung 26:1221-1223

Wicker P, Roudaut R, Gosse P, Dallocchio M (1984) Short and long-term treatment of mild to moderate hypertension with verapamil. In: Calcium antagonists and the treatment of hypertension: 45-54 Ed.: Reid JL and Pickup AJ, Royal Society of Medicine, London

Widener LL, Mela-Riker LM (1984) Verapamil pretreatment preserves mitochondrial function and tissue magnesium in the ischemic kidney. Circulatory Shock 13:27-37

Wigler I, Peex G, Soferman G, Blum M, Aviram A (1984) Long-term treatment of arterial hypertension with verapamil. International Journal of Clinicall Pharmacology, Therapy and

Zanchetti $A$, Leonetti $G$ (1985) Renal effects of calcium antagonists. In: Calcium and calcuum antagonists in hypertension. Proceedings of the Satellite Symposium to the 2nd European
Meeting on Hypertension. Milan, in press.

van Zwieten PA (1984) Calcium entry blockers (calcium antagonists). In: Handbook of Hypertension, vol 3, Pharmacology of antihypertensive drugs. pag. 331-342. Editor: PA van Zwieten, Elsevier, Amsterdam, New York, Oxford 


\section{Chapter 2 \\ Pharmacokinetics of Verapamil in Patients with Renal Failure*}

J. Mooy ${ }^{1}$, M. Schols ${ }^{2}$, M. w. Baak ${ }^{2}$, M. v. Hooff',

A.Muytjens", and K.H. Rahn ${ }^{1}$

1 Department of Internal Medicine,

Division of Nephrology, Hypertension and Clinical Pharmacology,

2 Department of Pharmacology and

3 Department of Statistics,

University of Limburg, Maastricht, The Netherlands

* Published in the European Joumal of Clinical Pharmacology (1985) 28: 405-410, and presented at the 9 th International Congress of Pharmacology, London, 1984. 
$$
\text { . }
$$ 


\section{Summary}

The pharmacokinetics of verapamil were studied in patients with end-stage chronic renal failure and in normal subjects after an intravenous injection of $3 \mathrm{mg}$ and a single oral dose of $80 \mathrm{mg}$ of the drug. Plasma levels of verapamil and its active metabolite norverapamil were measured by high-performance liquid chromatography. After intravenous injection, terminal phase half-life and total plasma clearance of verapamil were similar in both groups. Hemodialysis did not change the course of verapamil plasma levels after intravenous application. After a single oral dose, the plasma levels of verapamil and norverapamil were similar in both groups of subjects studied. Subsequently, normal volunteers and patients with renal failure were treated for 5 days with oral doses of 3 times $80 \mathrm{mg}$ verapamil per day. There were no differences between the 2 groups of subjects studied in the trough and peak levels of verapamil as well as of norverapamil. Intravenous and oral application of the calcium channel blocking agent had similar effects on blood pressure, heart rate and the PRinterval in the electrocardiogram in both groups. The study demonstrates that the disposition of verapamil is similar in normal subjects and in patients with renal failure.

\section{Introduction}

Although calcium entry blockers are frequently used in patients with renal failure, little is known about the disposition of these drugs in renal insufficiency. KEEFE et al. (1981) reported that patients with renal failure and normal subjects did not differ in the plasma protein binding of verapamil. The elimination half-life of diltiazem was found to be similar in patients with severe renal insufficiency and in subjects with normal kidney function (POzET et al. 1983).

In view of the lack of data concerning the disposition of calcium entry blockers in kidney failure a study was designed to compare the pharmacokinetics of verapamil in patients with terminal renal failure and in normal controls. Norverapamil is a metabolite of verapamil with about $20 \%$ of the calcium entry blocking activity of the parent drug (Neucebauek et al. 1978). Therefore, measurements of verapamil as well as of norverapamil were performed during the study. 


\section{Subjects and Methods}

Eight patients ( 4 men and 4 women) with severe kidney disease (endogenous creatinine clearance lower than $5 \mathrm{ml} / \mathrm{min}$ ) agreed to participate in the studies. All were in the chronic hemodialysis program. The age of the patients ranged from 25-75 years. Two of them were anuric after bilateral nephrectomy, 11 volunteers ( 7 males, 4 fermales, age 25-50 years) with normal kidney function (endogenous creatinine clearance higher than $90 \mathrm{ml} / \mathrm{min}$ ) served as controls. All subjects participating in the studies had normal liver function tests. Neither the patients nor the normal controls received antihypertensive treatment in the last month preceding the studies. On the days of the studies, patients and controls received no medication other than verapamil.

At first, 5 normal volunteers and 5 patients with renal failure were given an intravenous dose of $3 \mathrm{mg}$ verapamil. The patients with renal failure were studied in the interval between two dialyses. Prior to the injection of verapamil, 2 short catheters were placed in an antecubital vein of either arm. Thereafter, the subjects rested for $30 \mathrm{~min}$ in supine position. Then heart rate and blood pressure were measured, the PR-interval was determined and a blank blood sample was drawn. The dose of verapamil was dissolved in $5 \mathrm{ml} 0,9 \%$ saline solution and injected via one catheter within $5 \mathrm{~min} .10,30,60,90,120$, 180,240 , and $300 \mathrm{~min}$ after the start of the injection, blood samples were taken from the other catheter for measurement of plasma levels of verapamil and norverapamil. At the same time, blood pressure, heart rate and the PR-interval were recorded. In the 24 hours following the injection, urine was collected in the normal volunteers for determination of verapamil and norverapamil.

In 4 patients with renal failure, the same procedure was repeated during hemodialysis after an interval of at least one week. Verapamil was injected into the venous line of the artificial kidney $\left(1.2 \mathrm{~m}^{2}\right.$ cuprophane hollow liber kidney). The blood samples for measurement of verapamil and norverapamil were taken from the arterial line. Blood flow through the artificial kidney was $200 \mathrm{ml} / \mathrm{min}$, and diallysate flow was $500 \mathrm{ml} / \mathrm{min}$.

Six normal volunteers and 8 patients with renal failure received an oral dose of $80 \mathrm{mg}$ verapamil. The interval between the oral and the intravenous dose of the drug was at least one week in those subjects who participated in both studies. Immediately before as well as $30,60,90,120,180,240,300,360$ and 420 min after the oral dose of verapamil blood samples were taken for 
estimation of verapamil and norverapamil. At the same time; blood pressure, heart rate and the PR-interval were recorded. 24-hours urine samples were collected for determination of verapamil and norverapamil in the normal subjects and in the 4 patients with renal failure who had diuresis.

Subsequently, 8 normal volunteers and 5 patients with renal failure were treated for 5 days with $80 \mathrm{mg}$ verapamil 3 times per day orally. The doses were given at 9 a.m., 5 p.m. and 11 p.m.. On the sixth day, patients and controls rested from $8.30-9.00 \mathrm{a} . \mathrm{m}$. in supine position. Thereafter, blood pressure, heart rate and the PR-interval were recorded, and a blood sample was taken for the measurement of the trough levels of verapamil and norverapamil. This procedure was repeated 60 and $90 \mathrm{~min}$ after administration of $80 \mathrm{mg}$ verapamil orally. Furthermore, on the fifth day a 24-hours urine sample was collected for determination of verapamil and norverapamil in the normal subjects.

In one patient with renal insufficiency who was treated for several months with oral doses of 3 times $80 \mathrm{mg}$ verapamil per day, verapamil was determined in a sample of the dialysate collected during hemodialysis.

All blood pressure measurements were performed by means of an automatic recorder (Dinamap, Applied Medical Research Corporation, Tampa, U.S.A.). Heart rate and the PR-interval were determined from the electrocardiogram.

Blood was always collected into heparinized tubes and centrifuged immediately. The plasma was removed and kept frozen at $-20^{\circ} \mathrm{C}$. The urine samples were kept at the same temperature. Under these conditions, both verapamil and norverapamil concentrations remained constant for at least one month.

Verapamil and norverapamil were measured by means of a modification of the high-performance liquid chromatography technique described by HARAPAT and KATES $(1979,1980)$. The column used was a microsphere C-18 column $(100 \times 4.6 \mathrm{~mm})$. The mobile phase was a solution containing ammonium acetate, acetic acid, acetonitrile, and methanol in a volume ratio of 50: 4: 28: 10. The $\mathrm{pH}$ of the solution was adjusted to 2.5. This method is semsitive enough to determine verapamil and norverapamil concentrations of 2 $\mathrm{ng} / \mathrm{ml}$. In plasma from untreated subjects to which $25 \mathrm{ng} / \mathrm{ml}$ verapamil and norverapamil had been added, the coefficient of variation for the determination was $8.0 \%$ for verapamil and $7.0 \%$ for norverapamil $(n=7)$. 
Results are expressed as mean values \pm SEM with the number of determinations $(n)$ in brackets. Within-group comparisons of single values were made by using Student's $t$-test for paired data, and differences in single values between the 2 groups of subjects were analysed by Student's $t$-test for unpaired data. Differences between normal subjects and patients with renal failure in the plasma level curves of verapamil and norverapamil were tested by the oneway analysis of variance for response curves described by ZERBE (1979a). The verapamil plasma level curves obtained in patients with renal insufficiency during hemodialysis and in the dialysis interval were compared by the ramdomization test described by ZERBE (1979b).

The verapamil plasma level curves obtained after intravenous injection of the drug were analysed by means of a run-test (LIENERT 1973). The individual pharmacokinetic parameters were estimated by an iterative nonlineair least squares procedure (Dixom and Brown 1981).

The verapamil plasma level curves obtained after a single oral dose of $80 \mathrm{mg}$ of the drug were plotted on a semi-logarithmic scale. At first, the terminal phase half-life $(t / 2 \mathrm{~B})$ was calculated by linear regression analysis of the final linear slope. Thereafter, the area under the plasma concentration-time curve (AUCo- $)$ ) was determined by the trapezoidal method and extrapolation to infinity by dividing the last plasma concentration by $\mathbb{B}$. The apparent oral clearance (Clo) was obtained by dividing the dose by AUCo- $\infty$. The bioavailability $(\mathrm{F})$ was determined by dividing the dose-adjusted $\mathrm{AUC}$ - $\infty$ after oral administration by $A \mathrm{CC}_{0} \infty$ obtained after intravenous injection.

\section{Results}

\section{Pharmacokinetics after a single intravenous dose of verapamil.}

After intravenous injection of verapamil, plasma levels of the drug fell rapidly at first, followed by a more slow decline (Table 1). When compared by analysis of variance the plasma levels of the normal subjects and the concentrations found in patients with renal failure did not differ $(p>0.2)$. The verapamil plasma level curves could best be described by an open 2 -compartment model. Patients with macokinetic parameters (Table 2). The plasma concentrations of norver pharwere very low $(<6 \mathrm{ng} / \mathrm{ml})$ in both groups of subjects studied after intravenous injection of verapamil. Within 24 hours after the intects studied after intravenous the normal subjects excreted 77 . norverapamil in the urine. 
Table 1: Plasma concentrations of verapamil after $3 \mathrm{mg}$ of the drug given intravenously.

\begin{tabular}{c|c|c}
\hline \multirow{2}{*}{ Time (min) } & \multicolumn{2}{|c}{ Verapamil $(\mathrm{ng} / \mathrm{ml})$} \\
\cline { 2 - 3 } & $\begin{array}{c}\text { Controls } \\
(n=5)\end{array}$ & $\begin{array}{c}\text { Patients } \\
(n=5)\end{array}$ \\
\hline 10 & $47.0 \pm 22.2$ & $26.7 \pm 6.2$ \\
30 & $15.7 \pm 7.9$ & $12.5 \pm 1.6$ \\
60 & $11.2 \pm 1.6$ & $10.5 \pm 1.3$ \\
90 & $9.5 \pm 1.8$ & $8.7 \pm 2.1$ \\
120 & $8.4 \pm 0.4$ & $8.5 \pm 1.3$ \\
180 & $8.1 \pm 0.9$ & $7.1 \pm 0.9$ \\
240 & $7.1 \pm 1.1$ & $5.9 \pm 0.7$ \\
300 & $6.5 \pm 1.9$ & $5.5 \pm 0.7$ \\
\hline
\end{tabular}

Table 2: Pharmacokinetic parameters of verapamil after intravenous injection

\begin{tabular}{l|c|c|c}
\hline & $\begin{array}{c}\text { Controls } \\
(n=5)\end{array}$ & $\begin{array}{c}\text { Patients } \\
(n=5)\end{array}$ & $p$ \\
\hline $\mathrm{t} 1 / 2 \alpha(\mathrm{min})$ & $5.6 \pm 0.6$ & $14.9 \pm 4.1$ & $>0.05$ \\
$\mathrm{t} 1 / 2 \mathrm{~B}(\mathrm{~min})$ & $229 \pm 64$ & $261 \pm 16$ & $>0.3$ \\
$\left.\mathrm{AUCo}-\infty(\mathrm{ng} \cdot \mathrm{ml})^{-1} \cdot \mathrm{min}\right)$ & $5097 \pm 1243$ & $4518 \pm 772$ & $>0.3$ \\
$\mathrm{Cl}\left(\mathrm{ml} \cdot \mathrm{min}{ }^{-1}\right)$ & $685 \pm 136$ & $741 \pm 119$ & $>0.3$ \\
$\mathrm{Cl}\left(\mathrm{ml} \cdot \mathrm{min}^{-1} \cdot \mathrm{kg}^{-1}\right)$ & $9.2 \pm 1.9$ & $11.8 \pm 1.6$ & $>0.3$ \\
$\mathrm{~V}_{\mathbb{B}\left(1 . \mathrm{kg}^{-1}\right)}$ & $4.83 \pm 1.89$ & $4.42 \pm 0.6$ & $>0.4$ \\
\hline
\end{tabular}

$\mathrm{Cl}$ is te total plasma clearance

$V_{\mathbb{B}}$ the area volume of distribution 
The influence of verapamil intravenously on blood pressure, heart rate and PR-interval was tested 10 and $60 \mathrm{~min}$ after the injection. Prior to application of the drug, supine blood pressure was $132 \pm 9 / 76 \pm 4 \mathrm{mmHg}$ in the normal subjects and $152 \pm 7 / 80 \pm 6 \mathrm{mmHg}$ in the patients with renal failure. $10 \mathrm{~min}$ after injection of verapamil, the systolic blood pressure had fallen significantly $(p<0.02)$ to $126 \pm 8 \mathrm{mmHg}$ in the normal subjects and to $142 \pm 5 \mathrm{mmHg}$ in the patients. At this time, diastolic blood pressure had fallen $(p<0.01)$ to a level of $73 \pm 3 \mathrm{mmHg}$ in the patients with renal failure, whereas the diastolic blood pressure in the normal controls $(71 \pm 4 \mathrm{mmHg})$ did not differ $(p>0.05)$ from the value measured before injection of verapamil. The blood pressure data obtained $60 \mathrm{~min}$ after application of the drug did not differ from the pre-drug levels $(p>0.2)$.

Prior to injection of verapamil, heart rate was $79 \pm 4$ beats $/ \mathrm{min}$ in the normal subjects and $80 \pm 4$ beats/min in the patients with renal failure. The heart rate measured $10 \mathrm{~min}$ after injection of the drug did not differ from these values $(\phi>0.2)$. However, $60 \mathrm{~min}$ after application of verapamil heart rate had fallen $(p<0.05)$ to $76 \pm 3$ beats/min in the normal subjects and $71 \pm 3$ beats/min in the patients with renal failure. $90 \mathrm{~min}$ after the injection, heart rate had returned to the pre-drug levels in both groups.

Verapamil caused a prolongation $(p<0.05)$ of the PR-interval by $0.02 \mathrm{sec}$ in the normal subjects and by $0.025 \mathrm{sec}$ in the patients with renal failure $10 \mathrm{~min}$ after the intravenous injection. At $60 \mathrm{~min}$, the PR-intervals in normal subjects and patients did not differ from the values determined prior to application of verapamil $(p>0.2)$.

\section{Pharmacokinetics after a single oral dose of verapamil.}

Table 3 represents the plasma levels of verapamil and norverapamil after a single oral dose of $80 \mathrm{mg}$ of the drug. When tested by analysis of variance the verapamil plasma concentrations in the normal subjects and in the patients did not differ $(p>0.2)$. There was also no difference between the two groups of subjects studied in relevant pharmacokinetic parameters (Table 4). After oral application of verapamil, levels of the metabolite norverapamil in plasma were comparable with the concentrations of the parent drug (Table 3). There were no statistically significant differences $(\phi>0.3)$ between the normal subjects and the patients in the norverapamil plasma concentrations.

4 normal volunteers and 5 patients with renal failure received both an intravenous dose of $3 \mathrm{mg}$ and an oral dose of $80 \mathrm{mg}$ verapamil. The bioavailability $(F)$ as determined from the AUCo $\infty$ was $11 \pm 2 \%$ in the normal 
Table 3. Concentrations of verapamil and norverapamil in plasma after $80 \mathrm{mg}$ verapamil orally.

\begin{tabular}{|c|c|c|c|c|}
\hline \multirow[b]{2}{*}{$\begin{array}{l}\text { Time } \\
\text { (min) }\end{array}$} & \multicolumn{2}{|c|}{ Verapamil (ng/ml) } & \multicolumn{2}{|c|}{ Norverapamil (ng/ml) } \\
\hline & $\begin{array}{c}\text { Controls } \\
(n=6)\end{array}$ & $\begin{array}{c}\text { Patients } \\
(n=8)\end{array}$ & $\begin{array}{c}\text { Controls } \\
(n=6)\end{array}$ & $\begin{array}{c}\text { Patients } \\
(n=8)\end{array}$ \\
\hline 30 & $18.6 \pm 7.1$ & $48.5 \pm 24.2$ & $19.6 \pm 8.1$ & $24.3 \pm 11.2$ \\
\hline 60 & $47.5 \pm 9.1$ & $50.9 \pm 17.8$ & $50.4 \pm 14.2$ & $28.6 \pm 9.2$ \\
\hline 90 & $66.7 \pm 20.2$ & $51.7 \pm 12.9$ & $55.5 \pm 23.5$ & $31.5 \pm$ \\
\hline 120 & $35.0 \pm 5.5$ & $54.5 \pm 14.2$ & $53.7 \pm 7.7$ & $37.6 \pm$ \\
\hline 180 & $28.9 \pm$ & $47.4 \pm 13.5$ & $51.3 \pm$ & $43.0 \pm$ \\
\hline 240 & $20.0 \pm$ & $38.0 \pm 10.4$ & $42.3 \pm 6.2$ & $42.3 \pm$ \\
\hline 300 & $12.9 \pm$ & $27.7 \pm 6.5$ & $32.9 \pm$ & $38.8 \pm$ \\
\hline 360 & $10.3 \pm$ & $20.4 \pm 4.3$ & $29.5 \pm 4.6$ & $33.8 \pm$ \\
\hline 420 & $10.1 \pm$ & $18.9 \pm 3.7$ & $25.1 \pm 3.8$ & $30.3 \pm$ \\
\hline
\end{tabular}

Table 4: Pharmacokinetic parameters of verapamil after oral administration.

\begin{tabular}{|c|c|c|c|}
\hline & $\begin{array}{c}\text { Controls } \\
(n=6)\end{array}$ & $\begin{array}{l}\text { Patients } \\
(n=8)\end{array}$ & $p$ \\
\hline $\mathrm{T}_{\max }(\min )$ & $72 \pm 7$ & $92 \pm 22$ & $>0.1$ \\
\hline$t 1 / 2 B(\min )$ & $134 \pm 17$ & $161 \pm 12$ & $>0.1$ \\
\hline $\mathrm{AUCa}-\infty\left(\mathrm{ng} \cdot \mathrm{ml}^{-1} \cdot \mathrm{min}\right)$ & $10540 \pm 1093$ & $17818 \pm 4818$ & $>0.1$ \\
\hline $\mathrm{Cl}_{\mathrm{o}}\left(\mathrm{ml} \mathrm{min}^{-1}\right)$ & $8080 \pm 970$ & $8350 \pm 2580$ & $>0.4$ \\
\hline $\mathrm{Cl}_{\mathrm{O}}\left(\mathrm{milmin} \mathrm{min}^{-1} \cdot \mathrm{kg}^{-1}\right)$ & $137 \pm 19$ & $126 \pm 38$ & $>0.4$ \\
\hline
\end{tabular}

$\mathrm{T}_{\max }$ is the time of occurrence of the maximum plasma concentration $\mathrm{Cl}_{\mathrm{O}}$ is the oral clearance. 


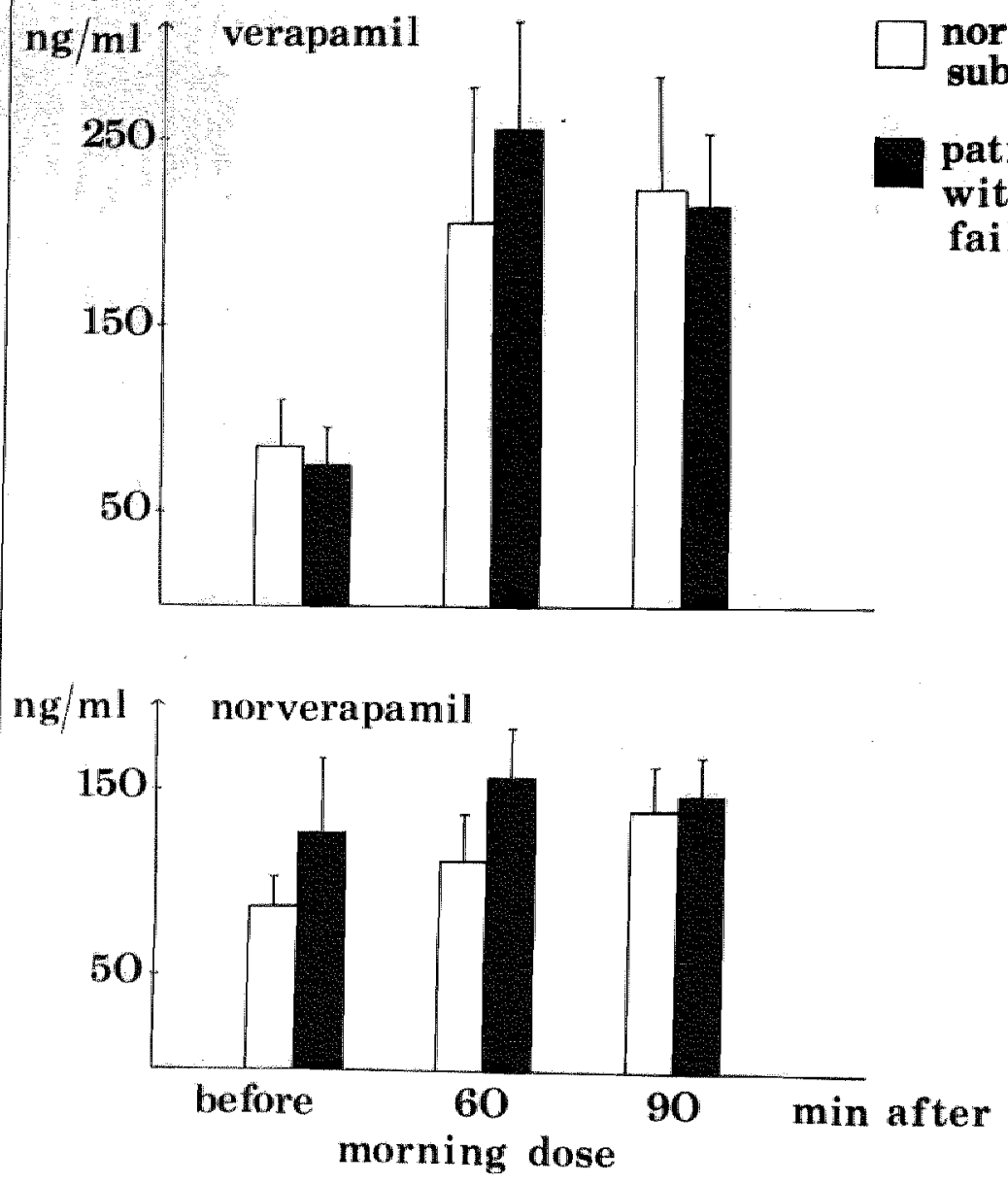

Fig. 1. Plasma levels of verapamil and norverapamil after a 5 days" oral treatment with verapamil 3 times $80 \mathrm{mg}$ per day. 
controls and $16 \pm 6 \%$ in the patients with renal insufficiency. The difference is statistically not significant $(\rho>0.2)$.

Within 24 hours after oral application of verapamil, the normal subjects excreted $90 \pm 45.9 \mu \mathrm{g}$ verapamil and $393 \pm 139.0 \mu \mathrm{g}$ norverapamil in urine. In the 4 patients with renal failure who had urine production, the respective values were $36 \pm 11.9 \mu \mathrm{g}$ for verapamil and $80 \pm 70.2 \mu \mathrm{g}$ for norverapamil. The differences between the two groups in the urinary excretion of verapamil and norverapamil are statistically significant $(\phi<0.05)$.

The influence of $80 \mathrm{mg}$ verapamil orally on blood pressure, heart rate and the PR-interval was tested 60 and $90 \mathrm{~min}$ after application of the drug. In both groups of subjects studied, the oral dose of verapamil had no influence on blood pressure $(p>0.05)$. Heart rate decreased $(\phi<0.05)$ from a pre-drug level of $73 \pm 7$ beats $/ \mathrm{min}$ to $67 \pm 6$ beats $/ \mathrm{min}$ in the normal controls and from $86 \pm$ 3 beats $/ \mathrm{min}$ to $78 \pm 4$ beats $/ \mathrm{min}$ in the patients with renal failure $90 \mathrm{~min}$ after oral application of verapamil. Heart rate data measured at 60 min did not differ from the pre-drug values. The PR-interval was prolonged $(p<0.05)$ by 0.03 sec in the control subjects and by 0.02 sec in the patients 60 min after oral application of verapamil with no prolongation measurable at $90 \mathrm{~min}$.

\section{Plasma levels of verapamil and norverapamil after 5 days oral treatment with verapamil.}

Fig. 1 shows the plasma levels of verapamil and norverapamil obtained on the sixth day prior to as well as 60 and $90 \mathrm{~min}$ after the morning dose when 8 normal subjects and 5 patients with renal failure had been treated for 5 days with $80 \mathrm{mg}$ verapamil orally 3 times per day. The two groups of subjects studied did not differ in the trough levels of both substances as well as in the concentrations measured after application of the morning dose $(\phi>0.1)$. In the normal subjects, 24-hours urinary excretion was $3.7 \pm 0.4 \mathrm{mg}$ for verapamil and $5.4 \pm 0.4$ $\mathrm{mg}$ for norverapamil on day 5 of continuous treatment with verapamil.

Neither in the normal subjects nor in the patients with renal failure did treatment with verapamil alter blood pressure and heart rate $(p>0.1)$. The drug prolonged $(p<0.05)$ the PR-interval in the patients by $0.02 \mathrm{sec}$. with no significant change $(p>0.05)$ in the normal subjects.

\section{$I V$. Influence of hemodialysis on verapamil plasma levels.}

Table 5 shows the verapamil plasma concentrations measured after intravenous injection of $3 \mathrm{mg}$ of the drug in 4 patients with renal failure during 
hemodialysis as well as in the dialysis interval. Data obtained during hemodialysis were somewhat higher than the values measured in the dialysis interval. The difference is, however, not statistically significant $(p>0.1)$.

In one patient with renal failure who received chronic treatment with verapamil 3 times $80 \mathrm{mg}$ per day orally, the concentration of the drug in the dialysate was determined. For this, the dialysate was collected for a period of 10 min (dialysate volume: $5000 \mathrm{ml}$ ). Verapamil plasma concentrations determined with blood drawn from the arterial line of the artificial kidney were almost identical at the beginning and at the end of the collection period and averaged to 56.1 $\mathrm{ng} / \mathrm{ml}$. The concentration of the drug in the dialysate was $3 \mathrm{ng} / \mathrm{ml}$. With these data, the verapamil clearance by the artificial kidney was calculated to be 27 $\mathrm{ml} / \mathrm{min}$.

Table 5: Plasma concentrations of verapamil ( $\mathrm{ng} / \mathrm{ml}$ ) after $3 \mathrm{mg}$ verapamil intravenously in 4 patients with renal insufficiency in an interval between dialyses and during hemodialysis.

\begin{tabular}{c|c|c}
\hline \multirow{2}{*}{ Time (min) } & \multicolumn{2}{|c}{ Verapamil $(\mathrm{ng} / \mathrm{m}$ ) } \\
\cline { 2 - 3 } & dialysis interval & during dialysis \\
30 & $20.4 \pm 4.0$ & $30.0 \pm 6.2$ \\
60 & $12.2 \pm 2.0$ & $17.1 \pm 4.0$ \\
90 & $8.7 \pm 0.9$ & $12.8 \pm 2.8$ \\
120 & $5.4 \pm 0.1$ & $12.1 \pm 2.7$ \\
180 & $6.7 \pm 0.9$ & $9.7 \pm 1.9$ \\
240 & $6.3 \pm 0.9$ & $5.2 \pm 1.9$ \\
$5.2 \pm 0.1$ & $3.0 \pm 1.4$ \\
\hline
\end{tabular}




\section{Discussion}

There are numerous reports on the pharmacokinetics of verapamil in subjects with normal kidney function (Schomerus et al. 1976, Koike et al. 1979 , Dominrc et al. 1981, Eichelbaum et al. 1981, Ma Allister and Kirsten 1982, Kates 1983). The pharmacokinetic parameters found in the present study are comparable with data reported by other authors. This is true for the terminal phase half-life of verapamil after intravenous injection of the drug (SCHомerus et al. 1976, Korke et al. 1979, Dominic et al. 1981) as well as for the maximum plasma concentration of verapamil after oral application and the time of its occurrence (Erchelbaum et al. 1981). After intravenous injection, the total plasma clearance of verapamil as determined in the present study is somewhat lower than the values published by several other investigators. There is, however, considerable variation of this parameter. As has been reported by MCALLISTER and KIRSTEN (1982) very little if any norverapamil could be detected in plasma after a single intravenous dose of verapamil. However, after single and repeated oral doses of verapamil plasma concentrations of the metabolite were comparable with the levels of the parent drug. The plasma levels of verapamil and norverapamil found after 5 days' treatment with oral doses of verapamil were similar as those reported by SchWARTz et al. (1982) and TARTAGLione et al. (1983).

In the present study, no differences were found between normal subjects and patients with renal failure in a number of pharmacokinetic parameters. Thus, the plasma level curves of verapamil were similar in both groups after intravenous and oral application of a single dose of the drug. The same holds true for the terminal phase half-life and total clearance after intravenous injection of verapamil as well as for the maximum plasma concentration and the time of its occurrence after a single oral dose of the drug. Furthermore, there were no differences between the 2 groups of subjects studied in the trough and peak levels of verapamil after 5 days' oral treatment with this agent. The plasma concentrations of the active metabolite norverapamil were also similar in both groups after oral treatment with the parent drug. Finally, the influence of werapamil on pharmacodynamic parameters such as blood pressure, heart rate and the $P R$-interval in the electrocardiogram was comparable in both groups. Taken together, this study demonstrates that the disposition of verapamil is similar in normal subjects and in patients with terminal renal failure. Therefore, there is no need to adjust. the doses of the calcium entry blocker depending upon the degree of renal impairment. 
The lack of influence of renal function on the disposition of verapamil in men is apparently due to the fact that only a small percentage of the drug is eliminated via the kidneys in unchanged form. In a study on the metabolism of ${ }^{14} \mathrm{C}$-verapamil, only $3-4 \%$ of the radioactivity excreted in urine corresponded with unchanged verapamil (ErCHELBAum et al. 1979). Similarly, in the present study the urinary excretion of unchanged verapamil always amounted to less than $5 \%$ of the doses applied.

Hemodialysis did not significantly alter the verapamil plasma level curve: obtained after intravenous injection of the drug in patients with renal insufficiency. As compared with the concomitantly measured plasma levels low concentrations of verapamil were found in the dialysate. The calculated verapamil clearance by the artificial kidney amounted to approximately $5 \%$ of the total plasma clearance. One may, thus, assume that little verapamil is eliminated by hemodialysis. This holds true for the type of artificial kidney used in the present study and probably also for other types and is apparently due to the high binding of verapamil to plasma proteins (KEEFE et al. 1981). Consequently, there is no need to adjust the dose of the calcium entry blocker in patients undergoing hemodialysis. 


\section{References}

Dixon WJ, Brown MB (1981) Biomedical Computer Programs P-series (BMDP-81). University of California Press, Berkeley, p 290-304

Dominic JA, Boume DWA, Tan TG, Kirsten EB, McAllister Jr RG (1981) The pharmacology of verapamil. III. Pharmacokinetics in normal subjects after intravenous drug administration. $J$ Cardiovase Pharmacol 3: 25-38

Eichelbaum M, Ende M, Remberg G, Schomerus M, Dengler HJ (1979) The metabolism of DL(1'C)-verapamil in man. Drug Met Disposition 7: 145-148

Eichelbaum M. Somogyi A, von Unruh GE, Dengler HJ (1981) Simultaneous determination of the intravenous and oral pharmacokinetic parameters of D, L-verapamil using stable isotopelabelled verapamil. Europ J Clin Pharmacol 19: 133*137

Harapat SR, Kates RE (1979) Rapid high-pressure liquid chromatography analysis of verapamil in blood and plasma. J Chromatography 170: 385-390

Harapat SR, Kates RE (1980) High-performance liquid chromatographic analysis of verapamil Ir. Simultaneous quantitation of verapamil and its active metabolite norverapamil. J Chromatography 181: 484-489.

Kates RE (1983) Calcium antagonists: pharmacokinetic properties, Drugs 25: 113-124

Keefe DL, Yee YG, Kates RE (1981) Verapamil protein binding in patients and in normal subjects. Clin Pharmacol Ther 29:21-26

Koike Y, Sthimamura K, Shudo I, Saito H (1979) Pharmacokinetics of verapamil in man. Res Comm Chem Pathol Pharmacol. 24:37-47

Lienert GA (1973) Verteilungsfreie Methoden in der Biostatistik. Verlag Anton Hein, Meisentheim, $\mathrm{p} 473$

McAllister RG, Kirsten EB (1982) The phamacology of verapamil. IV. Kinetic and dynamic effects after single intravenous and oral doses. Clin Pharm Ther 31: 418-426

Neugebauer $G(1978)$ Comparative cardiovascular actions of verapamil and its major metabolites in the anacsthetised dog. Cardiovasc Res 12: 247-254

Pozer N, Brazier JL, Hadj Aissa A, Khenfer D, Faucon $\mathrm{G}_{*}$ Apoil E, Traeger J (1983) Pharmacokinetics of diltiazem in severe renal failure. Eur J Clin Pharmacol 24: 635-638

Schomerus M, Spiegelhalder B, Stieren B, Eichelbaum M (1976) Physiological disposition of verapamil in man. Cardiovasc Res 10:605-612

Schwartz JB, Keefe DL, Kirsten $\mathbf{E}$, Kates RE, Harrison DC (1982) Prolongation of verapamil elimination kinetics during chronic oral administration. An Heart J 104: 198-203

Tartaglione TA, Pieper JA, Lopez LA, Mehta J (1983) Pharmacokinetics of verapamil and norverapamil during long-term oral therapy. Res Comm Chem Pathol Pharmacol 40:15-27

Zerbe GO (1979a) Randomization analysis of the completely randomized design extended to growh and response curves. J Amer Statist Association 74: 215-221

Zerbe GO (19796) Randomization analysis of randomized block design extended to growth and response curves. Commun Statist Theor Meth A8(2): 191-205. 


\section{Chapter 3}

\section{Studies on drug interactions with verapamil*}

J. Mooy ${ }^{1}$, R. Boehm ${ }^{\Perp}$, M. v. Baak ${ }^{2}$, J. v. Kemenade ${ }^{2}$, A. v.d. Vet ${ }^{3}$ and K.H. Rahn ${ }^{1}$

1 Department of Internal Medicine,

Division of Nephrology, Hypertension and Clinical Pharmacology,

2 Department of Pharmacology and

3 Department of Pulmonology,

University of Limburg, Maastricht, The Netherlands

* Submited for publication.

Part of the results was presented at the Joint Meeting of the Belgian, Dutch and German Pharmacological and Toxicological Societies in Aachen (Mooy et al. 1985a) and published in the New England Journal of Medicine (Rahn et al. 1985). 


\section{Summary}

The influence of 7 days' treatment with cimetidine on the plasma levels of verapamil given orally was studied in 6 patients. After oral application of 40 mg verapamil, the plasma levels of the drug as well as of its active metabolite norverapamil were not altered by pretreatment with cimetidine. The same is true for the time of the maximum verapamil plasma concentration as well as for the terminal phase half-life and the apparent oral clearance of verapamil.

Furthermore, the pharmacokinetics of verapamil given orally as well as intravenously were studied in patients treated with drugs for tuberculosis. 6 patients who had been treated for at least 6 months with a combination of rifampicin, ethambutol and isoniazid received a single oral dose of $40 \mathrm{mg}$ verapamil. As compared with untreated patients, the antituberculosis drugs strongly reduced the bioavailability of the calcium antagonist. Studies in patients in whom treatment with ethambutol and isoniazid had been discontinued revealed that this effect was due to rifampicin. The pharmacokinetics of verapamil given intravenously were not altered in patients treated with drugs for tuberculosis.

These findings can be explained by induction of verapamil metabolizing liver enzymes in patients treated with antituberculosis drugs.

This study shows that no adjustment of the verapamil dose is required in patients receiving cimetidine. However, in view of the reduced bioavailability the oral dose of the calcium antagonist has to be increased in patients treated with rifampicin.

\section{Introduction}

Verapamil is now frequently used for the treatment of hypertension. "The calcium antagonist is often given concomitantly with other drugs. Verapamil is extensively metabolized in man (Erchelbaum et al. 1979, Kates 1983). Experiments in animals demonstrated that the metabolism of the calcium antagonist takes place in the liver (HAMANN et al. 1984). Factors which alter liver function could, therefore, change the clearance of this drug. Cimetidine inhibits the oxydative drug metabolism by the liver and diminishes liver blood flow (FEELY et al. 1981, SEDMAN 1984). Rifampicin is a strong inductor of the hepatic drug metabolizing enzymes (BAciewicz et al. 1984). It is well known that cimetidine is able to inhibit the metabolism of drugs such as propranolol, 
metoprolol and theophylline (KLOtz et al. 1983, Mutschler et al. 1984). Furthermore, many drug interactions with rifampicin have been described (Kristensen 1976, Zilly et al. 1977, Baciewicz et al. 1984). Isoniazid, too, can possibly interfere with the metabolism of other drugs (ENGELHARD et al, 1984). There are conflicting results on the effect of cimetidine on the pharmacokinetics of verapamil (WiNg et al. 1983, SMith et al. 1984, CHo-MrNG Lol et al. 1985). There are no data concerning the influence of rifampicin on the disposition of verapamil. Therefore, the effects of cimetidine, rifampicin and other drugs for tuberculosis on the pharmacokinetics of the calcium antagonist were studied.

\section{Subjects and methods}

\section{PROTOCOL:}

Cimetidine-verapamil interaction study: 6 patients (1 woman, 5 men, age 27-71 years), agreed to participate in the study. Three patients had terminal renal failure (endogenous creatinine clearance $<5 \mathrm{ml} / \mathrm{min}$ ), necessitating regular intermittent hemodialysis. The other 3 patients had normal renal function (endogenous creatinine clearance $>90 \mathrm{ml} / \mathrm{min}$ ). All subjects had normal liver function tests (alkaline phosphatase, gamma-glutamyl transpeptidase, transaminases). They received no drugs other than verapamil and cimetidine at the time of the study.

At first, all subjects received one single oral dose of $40 \mathrm{mg}$ verapamil. Prior to the application of the calcium antagonist, a short catheter was placed in an antecubital vein of one arm. Immediately before as well as at $30,60,90$, $120,180,240,300,360$ and $420 \mathrm{~min}$ after the oral dose of verapamil blood samples were taken via the catheter for measurement of plasma levels of verapamil and its metabolite norverapamil. At the same time, supine blood pressure and heart rate were determined in 3 of the patients.

Thereafter, all patients were treated with cimetidine for 7 days. The patients with normal kidney function received $1000 \mathrm{mg}$ cimetidine daily, the patients with terminal renal failure $400 \mathrm{mg}$ daily. On the 7 th day of the study, all patients again received an oral dose of $40 \mathrm{mg}$ verapamil and the collection of blood samples as well as the measurements of blood pressure and heart rate were repeated. 
Rlfampicin-verapamil interaction study: 6 patients (age 30-70 years, 2 women, 4 men) who were being treated with drugs for tuberculosis for at least 6 months, participated in this part of the study. All parients had normal liver function tests. One patient had terminal renal failure and was in the chronic hemodialysis program. The renal function of the other patients was normal. In none of the subjects studied, there were symptoms or laboratory parameters suggesting disturbances of intestinal absorption. The drugs and the doses used were rifampicin 450-600 $\mathrm{mg} /$ day, isoniazid $5 \mathrm{mg} / \mathrm{kg} / \mathrm{day}$ and ethambutol 15 $\mathrm{mg} / \mathrm{kg} / \mathrm{day}$. All patients received one oral dose of $40 \mathrm{mg}$ verapamil. Immediately before as well as repeatedly after application of the calcium antagonist, blood samples were taken for determination of the plasma levels of verapamil and norverapamil as has been described for the cimetidineverapamil interaction study. At the same time, supine blood pressure and heart rate were measured in all patients.

In 2 patients this procedure was repeated after discontinuation of isoniazid and ethambutol for one month and again one month after rifampicin was discontinued, too.

4 patients were also given an intravenous dose of $3 \mathrm{mg}$ verapamil while being treated with drugs for tuberculosis. The dose of the calcium antagonist was dissolved in $5 \mathrm{ml} 0.9 \%$ saline and injected into a peripheral vein within $5 \mathrm{~min}$. Blood samples were taken from a contralateral vein immediately before as well as at $10,30,60,90,120,180,240$ and $300 \mathrm{~min}$ after the start of the injection for measurement of verapamil and norverapamil. The pharmacokinetic data of verapamil intravenously in these patients were compared with the data from 4 healthy subjects (age $40-70$ years).

The normal subjects received no drugs other than verapamil at the time of the study.

All blood pressure measurements were performed by means of an automatic recorder (Dinamap, Applied Medical Research Corporation, Tampa, U.S.A.). Blood was always collected into heparinized tubes and centrifuged immediately. The plasma was removed and kept frozen at $-20^{\circ} \mathrm{C}$.

\section{Analytical and statistical methods}

Plasma levels of verapamil and norverapamil were determined by means of high-performance liquid chromatography as described earlier (Moov et al. 
1985b). This method is sensitive enough to determine verapamil and norverapanil concentrations of $2 \mathrm{ng} / \mathrm{ml}$. The recovery of verapamil and norverapamil added to plasma from patients treated with cimetidine, or with the combination of isoniazid, ethambutol and rifampicin was identical with the recovery of the calcium antagonist and its metabolite from plasma of untreated subjects.

The verapamil plasma level curves obtained after a single oral dose of $40 \mathrm{mg}$ and after an intravenous injection of $3 \mathrm{mg}$ of the drug were platted on a semilogarithrnic scale. At first, the terminal phase half- $\|$ ife $(t / 2 \beta)$ was calculated by linear regression analysis of the terminal linear slope. Thereafter, the area under the plasma concentration-time curve ( $A \cup C_{0-\infty}$ ) was determined using the trapezoidal method and extrapolation to infinity by dividing the last plasma concentration by $\beta$. The apparent oral clearance ( $\mathrm{Clo}$ ) as well as the total plasma clearance (Cl) after intravenous injection was obtained by dividing the dose by

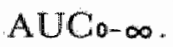

All data are given as mean \pm SEM with the number of determinations $(n)$ in brackets. Within-group comparisons of single values were made using Student's $t$-test for paired data and differences of single values between two groups were analysed by Student's $t$-test for unpaired data. Differences between plasma level curves were tested by means of a randomization test described by ZERBE (1979).

\section{Results}

\section{Cimetidine-verapamil interaction study:}

The plasma levels of verapamil and norverapamil after $40 \mathrm{mg}$ verapamil orally before and after treatment with cimetidine are given in Table 1 . When compared by analysis of variance, verapamil plasma levels of the 6 patients before and after treatment with cimetidine did not differ $(p>0.2)$.

Pharmacokinetic data as calculated from the verapamil plasma level curves are given in Table 2. These parameters did not differ when determined before and during treatment with cimetidine.

There was also no difference between the dialysis patients and the patients with normal renal function in plasma levels and pharmacokinetic data of verapamil before and after cimetidine $(p>0.2)$.

The influence of $40 \mathrm{mg}$ verapamil orally on blood pressure and heart rate was tested 60 and $90 \mathrm{~min}$ after application of the drug.

Verapamil had no influence on systolic and diastolic blood pressure as well as on heart rate before and after treatment with cimetidine $(p>0.1)$. 
Table 1: Plasma concentrations of verapamil and norverapamil after $40 \mathrm{mg}$ verapamil orally $(n=6)$

\begin{tabular}{|c|c|c|c|c|}
\hline \multirow[b]{2}{*}{$\begin{array}{l}\text { Time } \\
\text { (min) }\end{array}$} & \multicolumn{2}{|c|}{ Verapamil (ng/ml) } & \multicolumn{2}{|c|}{ Norverapamil (ng/ml) } \\
\hline & $\begin{array}{c}\text { before } \\
\text { cometidine }\end{array}$ & $\begin{array}{c}\text { with } \\
\text { cimetidine }\end{array}$ & $\begin{array}{c}\text { before } \\
\text { cimetidine }\end{array}$ & $\begin{array}{c}\text { with } \\
\text { cimetidine }\end{array}$ \\
\hline 0 & 0 & 0 & 0 & 0 \\
\hline 30 & $4.7 \pm 4.5$ & $4.7 \pm 3.7$ & $1.7 \pm 1.7$ & $1.4 \pm 1.4$ \\
\hline 60 & $32.2 \pm 9.7$ & $31.0 \pm 5.8$ & $14.7 \pm 4.6$ & $12.4 \pm 1.5$ \\
\hline 90 & $35.7 \pm 5.4$ & $41.1 \pm 6.7$ & $22.6 \pm 3.6$ & $21.0 \pm 2.3$ \\
\hline 120 & $29.2 \pm 4.2$ & $31.8 \pm 4.8$ & $22.9 \pm 2.3$ & $19.6 \pm 1.8$ \\
\hline 180 & $22.1 \pm 4.1$ & $27.9 \pm 6.3$ & $21.2 \pm 1.4$ & $20.7 \pm 2.5$ \\
\hline 240 & $15.7 \pm 3.8$ & $22.2 \pm 5.3$ & $20.2 \pm 2.5$ & $21.6 \pm 2.0$ \\
\hline 300 & $13.4 \pm 1.7$ & $17.0 \pm 4.1$ & $18.0 \pm 1.0$ & $19.5 \pm 2.2$ \\
\hline 360 & $10.8 \pm 2.0$ & $13.3 \pm 2.3$ & $16.8 \pm 1.9$ & $19.1 \pm 1.9$ \\
\hline 420 & $8.9 \pm 2.0$ & $9.7 \pm 2.6$ & $14.6 \pm 1.4$ & $14.7 \pm 2.3$ \\
\hline
\end{tabular}

Table 2: Pharmacokinetic parameters of verapamil after oral administration of $40 \mathrm{mg}(n=6)$

\begin{tabular}{l|c|c|c}
\hline & before cimetidine & with cimetidine & $p$ \\
\hline $\mathrm{C}_{\max }(\mathrm{ng} / \mathrm{ml})$ & $39.5 \pm 7.6$ & $41.2 \pm 6.7$ & $>0.3$ \\
$\mathrm{~T}_{\max (\mathrm{min})}$ & $85 \pm 9$ & $105 \pm 15$ & $>0.1$ \\
$\mathrm{t}^{1 / 2} \beta(\mathrm{min})$ & $191 \pm 29$ & $154 \pm 12.6$ & $>0.05$ \\
$\mathrm{AUCo} \infty\left(\mathrm{ng} \cdot \mathrm{ml}^{-1} \cdot \mathrm{min}\right)$ & $9938 \pm 1593$ & $11149 \pm 1944$ & $>0.1$ \\
$\mathrm{Cllo}\left(\mathrm{ml} \cdot \mathrm{min}^{-1}\right)$ & $4572 \pm 699$ & $4507 \pm 1115$ & $>0.4$ \\
\hline
\end{tabular}

$\mathrm{C}_{\max }$ is the maximum plasma concentration

$T_{\max }$ is the time of the maximum plasma concentration

$t 1 / 2 \beta$ is the half-life of the terminal phase of the plasma level curve

AUCo- $\infty$ is the area under the plasma concentration-time curve

Clo is the apparent oral clearance 


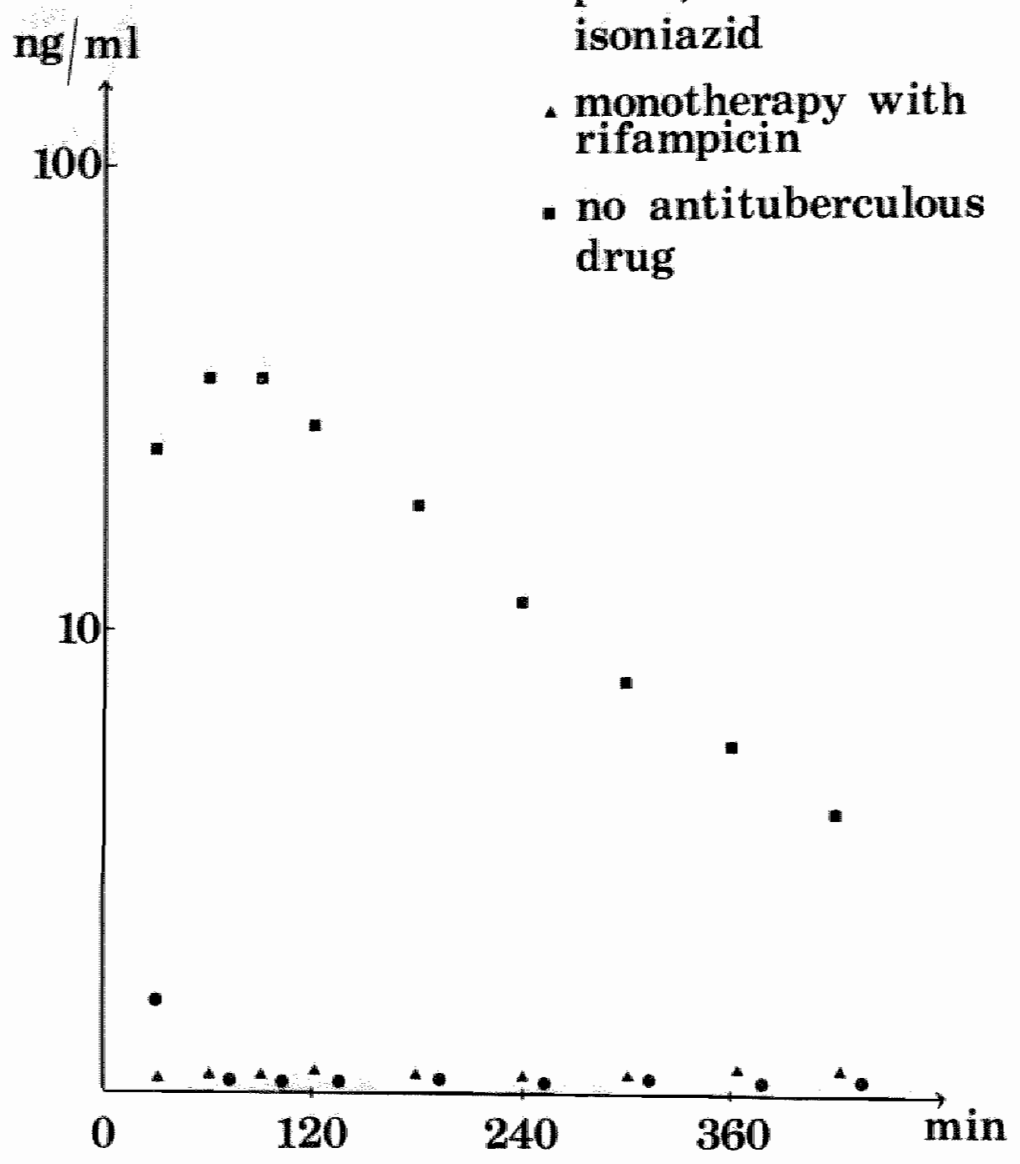

- combination of rifampicin, ethambutol and isoniazid

monotherapy with rifampicin

- no antituberculous drug 


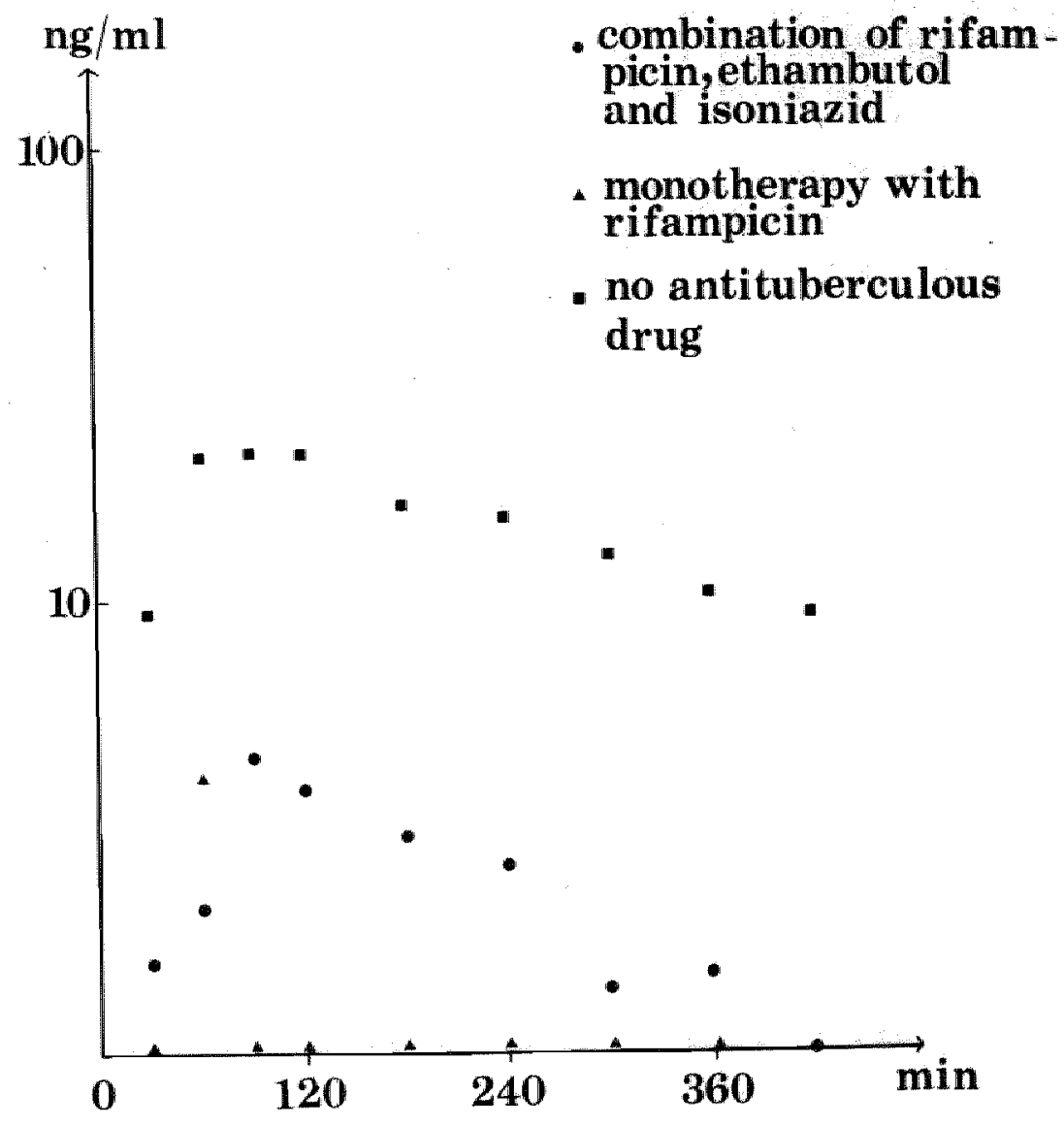

Fig. 2. Norverapamil plasma levels after $40 \mathrm{mg}$ verapamil orally. Mean values of two patients. 
Rifampicin-verapamil interaction study:

After an oral dose of $40 \mathrm{mg}$ verapamil, the plasma levels of the calcium antagonist and of its metabolite norverapamil were extremely low in the 6 patients treated with antituberculosis drugs as compared with untreated subjects ( $c$. Table 1), The rnaximum plasma concentration of verapamil was $20.3 \mathrm{ng} / \mathrm{ml}$ in one of the patients on antituberculosis drugs and less than $5 \mathrm{ng} / \mathrm{ml}$ in the 5 other ones. The maximum norverapamil concentration was $28.2 \mathrm{ng} / \mathrm{ml}$ in one patient treated with antituberculosis agents, and less than $10 \mathrm{ng} / \mathrm{ml}$ in the other ones.

Because of the very low concentrations of verapamil in these patients, the halflife of the terminal phase, the area under the plasma concentration-time curve and the apparent oral clearance could not be calculated.

Table 3: Verapamil plasma levels after $3 \mathrm{mg}$ intravenously $(\mathrm{ng} / \mathrm{ml})$

\begin{tabular}{c|c|c} 
Time (min) & $\begin{array}{c}\text { Normal subjects } \\
(n=4)\end{array}$ & $\begin{array}{c}\text { Patients with } \\
\text { antituberculous therapy } \\
(n=4)\end{array}$ \\
\hline 10 & $31.8 \pm 9.9$ & $20.4 \pm 3.4$ \\
30 & $14.0 \pm 0.6$ & $13.1 \pm 0.9$ \\
60 & $10.0 \pm 0.6$ & $9.6 \pm 0.5$ \\
90 & $7.9 \pm 0.6$ & $8.1 \pm 1.1$ \\
120 & $7.1 \pm 0.7$ & $6.2 \pm 0.3$ \\
180 & $5.2 \pm 0.7$ & $5.2 \pm 0.1$ \\
240 & $4.0 \pm 0.9$ & $4.8 \pm 0.9$ \\
300 & $4.9 \pm 1.0$ \\
\hline
\end{tabular}

Table 4: Pharmacokinetic parameters of verapamil after $3 \mathrm{mg}$ intravenously

\begin{tabular}{l|c|c|c}
\hline & $\begin{array}{c}\text { Normal subjects } \\
(n=4)\end{array}$ & $\begin{array}{c}\text { Patients with anti- } \\
\text { tuberculous therapy } \\
(n=4)\end{array}$ & $p$ \\
\hline $\mathrm{t} / 2 \beta(\mathrm{min})$ & $196 \pm 65$ & $234 \pm 37$ & $>0.3$ \\
$\mathrm{AUC0} \infty\left(\mathrm{ng} \cdot \mathrm{ml}^{-1} \cdot \mathrm{min}\right)$ & $4428 \pm 1403$ & $3342 \pm 300$ & $>0.2$ \\
$\mathrm{Cl}\left(\mathrm{ml} . \mathrm{min}^{-1}\right)$ & $842 \pm 180$ & $921 \pm 89$ & $>0.3$ \\
$\mathrm{Cl}\left(\mathrm{ml} . \mathrm{min}^{-1} \cdot \mathrm{kg}^{-1}\right)$ & $11.3 \pm 2.6$ & $14.6 \pm 1.8$ & $>0.15$ \\
\hline
\end{tabular}


The influence of verapamil on the blood pressure and heart rate was tested in these patients 60 and $90 \mathrm{~min}$ after application of the dose. There was no influence on the systolic and the diastolic blood pressure and on heart rate $(p>0.1)$.

2 patients were studied at first during treatment with the combination of rifampicin, ethambutol and isoniazid. The study was repeated after discontinuation of isoniazid and ethambutol for one month and again one month after rifampicin had been discontinued, too. Minimal concentrations of verapamil and norverapamil were detected in plasma during treatment with the combination of 3 antituberculous drugs as well as during monotherapy with rifampicin (fig. 1 and 2). However, the plasma levels of verapamil and norverapamil determined in these patients after discontinuation of rifampicin were comparable with the concentrations found in patients who had received no drugs for treatment of tuberculosis (Table 1).

Table 3 shows the plasma levels of verapamil after $3 \mathrm{mg}$ given intravenously in normal subjects and in patients with antituberculosis therapy. The plasma concentrations did not differ $(p>0.2)$.

There were also no statistically significant differences between the two groups in the relevant pharmacokinetic parameters (Table 4). No norverapamil was detected in plasma after intravenous injection of verapamil.

\section{Discussion}

The present study confirms previous findings (Mooy et al. 1985b) that the pharmacokinetics of verapamil do not differ in normal subjects and in patients with terminal renal failure. Therefore, in our study on the effects of cimetidine on the pharmacokinetics of verapamil, the data of both groups were pooled. Our data do not show any influence of cimetidine on relevant pharmacokinetic parameters of verapamil. However, conflicting results on the effect of cimetidine on the disposition of verapamil have been published. Cho-MLing Lor et al. (1985) found that $1200 \mathrm{mg}$ cimetidine daily for 5 days slightly reduced the clearance of intravenously given verapamil. WING et al. (1983), however, did not find an effect of one week pretreatment with cimetidine (1000 mg daily) on the clearance of verapamil given intravenously or orally.

These results are in accordance with the observations of SMITH et al. (1984). They also did not find a statistically significant effect of 8 days pretreatment with cimetidine $1200 \mathrm{mg}$ daily on the clearance of oral and intravenous verapamil. In this study, however, a significant increase in the bioavailability 
of oral verapamil was described after pretreatment with cimetidine. After treatment with cimetidine the AUC of verapamil intravenously was somewhat, but not statistically siginificant, lower than the AUC before treatment. This result is surprising and cannot easily be interpreted. The AUC after oral application was slightly higher after treatment with cimetidine. This resulted in a statistically significant difference of the quotient of both of them (bioavailability) before and after treatment with cimetidine.

Feely et al. (1984) suggested a possibly dose dependent effect of cimetidine on the oxydative metabolism in the liver.

In view of the published data and our results, it can be concluded that with usual doses of cimetidine there is little if any influence of this drug on the metabolism of verapamil. Therefore, there is no need to adjust the dose of the calcium antagonist in patients receiving cimetidine.

After oral application of verapamil, the plasma levels of the drug and also of its active metabolite norverapamil were extremely low in patients treated with antituberculosis drugs. Control experiments with verapamil and norverapamil added to plasma from patients treated with antituberculosis drugs showed that this observation was not due to interference with the assay procedure for the calcium antagonist and its metabolite. The most likely explanation for the low verapamil plasma levels observed in patients during treatment with drugs for tuberculosis is an induction of drug metabolizing liver enzymes by rifampicin (KRISTENSEN 1976, ZuLLY et al. 1977, Baciewicz et al. 1984). One must assume that the enzyme induction also causes accelerated metabolism of norverapamil.

However, the patients with tuberculosis were treated with a combination of rifampicin, ethambutol and isoniazid. Thus, it was not clear which of the drugs for tuberculosis had caused enzyme induction. Therefore, the study was repeated in two patients after discontinuation of ethambutol and isoniazid as well as after treatment with rifampicin had been finished, too. The results demonstrate that monotherapy with rifampicin leads to extremely low plasma levels of verapamil and norverapamil after oral application of the calcium antagonist. On the basis of these experiments, one may conclude that rifampicin causes induction of the enzymes which metabolize verapamil and norverapamil. A contribution of isoniazid and/or ethambutol can, however, not be excluded. 
After intravenous injection of verapamil, the plasma levels and the pharmacokinetic parameters of the drug as observed in normal subjects were comparable with published data (Dominic et al. 1981, Mooy et al. 1985b). No norverapamil could be detected in plasma after intravenous injection of $3 \mathrm{mg}$ verapamil. This is in accordance with data published by McAluster et al. (1982) and Moor et al. (1985b). In patients treated with antituberculosis drugs, the plasma levels of verapamil were almost identical with the concentrations found in untreated subjects.

If one assumes that treatment with rifampicin causes induction of verapamil metabolizing liver enzymes this would cause an increase of intrinsic liver clearance of the calcium antagonist. As has been shown by WHKINSON and SHAND (1975), enhancement of intrinsic clearance leads to a substantial decrease of plasma levels after oral application with little or no change after intravenous injection of a high clearance drug like verapamil. Hence the findings with oral and intravenous administration of verapamil support the idea that rifampicin causes induction of liver enzymes which metabolize the calcium antagonist.

On the basis of the present study one may assume that the bioavailability of verapamil given orally is strongly diminished in patients treated with rifampicin. As a consequence, the oral dose of the calcium antagonist has to be increased in such patients in order to obtain therapeutic plasma levels. 


\section{References}

Baciewicz AM, Self TH (1984) Rifampin drug interactions. Arch Int Med 144: 1667-1671

Cho-Ming Loi, Rollins DE, Dukes GE, Peat MA (1985) Effect of cimetidine on verapami disposition. Clin Pharmacol Ther 37: 654-657

Dominic JA, Boume DWA, Tan TG, Kirsten EB, McAllister RG Jr (1981) The pharmacolog) of verapamil. III. Pharmacokinetics in normal subjects after intruvenous drug administration $J$ of Cardiovatse Pharmacol 3: 25-38

Fichellbaum M, Ende $M$, Remberg $G$, Schomenus M, Dengler HI (1979) The metabolism a DL ( ${ }^{14} \mathrm{C}$ )-verapamil in man. Drug Metab Dispos 7: 145-148

Engelhard D, Stutman HR, marks MI (1984) Interaction of ketoconazole with rifampicin anc isoniazid. New Engl J of Med 311: 1681-1683

Feely J. Wilkinson $\mathrm{G}$, Wood A (1981) Reduction of liver blood flow and propranolol metabolism by cimetidine. New Engl I of Med 304: 692-695

Feely J, Pereira L, Guy E, Hockings N (1984) Factors affecting the response to inhibition of drug metabolism by cimetidine - dose response and sensivity of elderly and induced subjects. Br J Clin Pharmacol 17: 77-81

Hamann SR, Blowin RA, McAllister RG Jr (1984) Clinjcal pharmacokinetics of verapamil. Clinical Pharnacokinetics 9: 26-41

Kates RE (1983) Calcium antagonists: pharmacokinetic properties. Drugs 25: 113-124

Klotz U, Reimann I (1983) Einfluss von Mistamin $\mathrm{H}_{2}$-Rezeptorantagonisten auf die hepatische Elimination von Arzneimitteln. Klinische Wochenschrift 61: 625-632

Kristensen MB (1976) Drug interactions and clinical pharmacokinetics. Chinical Pharmacokinetics $1: 351.372$

McAllister RG, Kirsten EB (1982) The pharmacology of verapamil. IV. Kinetic and dynamic effects after single intravenous and oral doses. Clin Pharmacol Ther 31: $418-426$

Mooy J, Bochm R, van Haak M, van Kemenade J. Rahn KH (1985a) Treatment with anvimberculosis drugs strongly reduces the bioavailability of oral verapamil. NaturynSchmiedeberg's Archives of Pharmacology 330 Suppl: R79

Mooy J, Schols M, van Baak M, van Hoof M, Muyjens A, Rahn KH (1985b) Pharmacokinetics of verapamil in patients with renal fallure. Bur J Clin Pharmacol 28: 405-410

Mutschler $\mathbb{E}$, Spahn $H_{0}$ Kirch $W$ (1984) The interaction betweon $H 2$ receptor antagonists amal beta-adrenoceptor blockers. Br. I Chin Pharmacol 17:515-575

Rahn KH, Mooy J, Boehm R, v.d. Vet A (1985) Reducton of biovallability of werapamil by rifampicin. New Engl J of Mod 312: 920-921

Sedman AJ (1984), Cimetidine-drug interactions. Am J Med 76: 109-114

Smuth MS, Benyunes MC, Bjornsson TD, Shand DG, Pritchet FIC (1984) Inhuencio of cimetidine on werapamil kinetics and dynamics. Clin Pharmatol Ther 36:551-554 
Wilkinson $\mathrm{RG}$, Shand $\mathrm{DG}$ (1975) A physiological approach to hepatic drug clearance. Clin Pharmacol Ther 18: $377-390$

Wing LMH, Miners JO, Lillywhite $\mathrm{K}$, Harrington $\mathrm{B}$ (1983) Verapamil disposition-effects of susphinpyrazone and cimetidine. Abstracts II Wond Conference on Clinical Pharmacology and Therapeutics, Washington D.C. (U.S.A.).

Zeerbe GO (1979) Randomization analysis of randomized block design extended to growth and response curves. Commun Stat Theor Methodol A8 [2]: 191-205

Zilly W, Breimer DD, Richter E (1977)Pharmacokinetic interactions with rifampicin. Clin Pharmacokinetics 2: $61-70$ 


\section{Chapter 4}

\section{Influence of prolonged submaximal}

exercise on the pharmacokinetics of verapamil in man.*

J. Mooy ${ }^{1}$, B. Arends ${ }^{2}$, J. v. Kemenade ${ }^{2}$, R. Boehm ${ }^{1}$, K.H. Rahn ${ }^{1}$, and M.v. Baak ${ }^{2}$

1 Department of Medicine,

Division of Nephrology, Hypertension and Clinical Pharmacology

2 Department of Pharmacalogy and

University of Limburg, Maastricht, The Netherlands

* Accepted for penblication in the Journal of Cardiovascular Pharmacology 


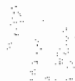

$\therefore$ 


\section{Summary}

The influence of prolonged submaximal exercise on the pharmacokinetics of verapamill was studied in normal volunteers both after intravenous injection of $0.13 \mathrm{mg} / \mathrm{kg}$ body weight as well as after an oral dose of $80 \mathrm{mg}$ of the calcium entry blocker. Each dose was given on a rest day and on an exercise day. On the exercise day, the subjects performed prolonged submaximal work on a bicycle ergometer. The verapamil plasma levels were determined using highperformance liquid chromatography. On the rest day, the terminal phase halflife of verapamil averaged to $161 \pm 23 \mathrm{~min}$ after intravenous injection of the drug. "The total clearance was $772 \pm 125 \mathrm{ml} / \mathrm{min}$, the area volume of distribution was $198 \pm 531$. These parameters were not altered on the exercise day. Exercise had also no influence on the pharmacokinetic parameters determined after oral application of verapamil. In contrast, exercise reduced the total clearance of indocyanine green by $30 \%$, reflecting reduction of liver perfusion by the physical activity. The study shows that prolonged submaximal exercise has no influence on the pharmacokinetics of verapamil. Therefore, there is no need for adjusting the doses of the drug in patients undergoing regular exercise.

\section{Introduction}

There are several studies on the hemodynamic actions of calcium entry blockers during exercise in man (Exelund et al. 1982, Franz and Wiewel 1984, Lund-Johansen 1984, Stern et al. 1984). However, little is known about the influence of exercise on the pharmacokinetics of these drugs. During exercise, blood flow through the intestine and the liver decreases (Rowell et al. 1964, Swartz et al. 1974). This can influence both intestinal absorption and hepatic clearance of drugs. Other pharmacokinetics which can change during exercise are the volume of distribution (SWEENEY et al. 1981) and the plasma protein binding (Evans et al. 1973).

Recently, Arenss et al. (1985) have demonstrated that the half-life of the beta-receptor blocking agent propranolol decreases during prolonged submaximal exercise. The pharmacokinetics of the calcium entry blocker verapamil resemble those of propranolol. Like propranolol, verapamil undergoes substantial first-pass metabolism in the liver. The drug is highly bound to plasma proteins with an apparent volume of distribution of 3.5-6 $1 / \mathrm{kg}$ body weight. The elimination of verapamil is mainly through metabolism 
by the liver with a half-life of $2-5$ hours (KATES 1983, HAMANN et al. 1984 Moor et al. 1985). Thus, it seemed possible that, as with propranolol, the kinetics of verapamil, are altered by physical exercise. The present study wa designed to test this possibility.

\section{Subjects and methods}

The study consisted of 2 parts: one with verapamil given intravenously and the other one with oral application of the calcium antagonist. In total, 10 health; volunteers with age ranging from 20-35 years participated in the study, in the intravenous study 5 men and 1 woman, in the oral study 4 men and 2 women All subjects had normal blood pressure as well as normal liver and kidney func tion. All gave informed consent. The study wass approved by the Ethics Com mittee of the University of Limburg Medical School.

At first, maximum work load (Wmax) cluring bicycle ergometry wa: determined. The subjects started with a work load of $100 \mathrm{Watt}$ lasting $4 \mathrm{~min}$ The work load was increased step-wise by 50 Watt every $3 \mathrm{~min}$. As soon a heart rate exceeded 150 beats $/ \mathrm{min}$, the work load was increased by 20 Wat every $3 \mathrm{~min}$. Wmax was defined as the work load where either heart rate dic not increase further or where the subjects became exhausted.

Not earlier than one week after determination of the maximal worl capacity, the subjects came back to the laboratory. They were studied one das during exercise and on another day at rest. Rest and exercise day were ran domized. There was an interval of at least one week between the two days. Or the study days, a catheter was placed in an antecubital vein for drawing bloo samples. After $30 \mathrm{~min}$ rest, blood pressure and heart rate were measured in sit ting position and a blank blood sample was taken. Then $0.13 \mathrm{mg} / \mathrm{kg}$ body weigh verapamil dissolved in $10 \mathrm{mll} 0.9 \%$ sodium chloride was given intravenously vi: a contralateral vein over a period of $10 \mathrm{~min}$ (intravenous study) or $80 \mathrm{~ms}$ verapamil was given orally (oral study).

On the exercise day, the subjects started exercise on a bicycle ergometer at $50 \%$ of the predetermined maximum work load (W max) 30 min after verapamil har been given. After $20 \mathrm{~min}$, the subjects stopped exercise and walked around for half an hour. Then, after $5 \mathrm{~min}$ in sitting position, blood pressure and heart rate were measured and a blood sample was taken via the catheter for the determina tion of plasma levels of verapamil and of its metabolite norverapamil. This pro cedure was repeated every hour for a period of 7 hours. 
On the rest day, the volunteers stayed in sitting position for a period of 7 hours.

In 4 subjects participating in the intravenous study, indocyanine green clearance was determined on the rest and on the exercise days, respectively. For this, $25 \mathrm{mg}$ indocyanine green was injected intravenously $5 \mathrm{~min}$ after starting exercise during the second ergometry period of the exercise day. Blood samples were taken $3,5,7,9,11$ and $15 \mathrm{~min}$ after the injection for measurement of plasma indocyanine green levels. On the rest day, the measurements were performed at the same time.

Blood pressure was always measured using a Dinamap automatic recorder (Applied Medical Research Corporation, Tampa, U.S.A.). Verapamil and norverapamil plasma levels were determined using high-performance liquid chromatography as described earlier (Moov et al. 1985). The measurements of indocyanine green were performed immediately after blood sampling. Proteins were removed from the plasma by mixing with aceton and centrifuging for 20 min according to SVENNSON et al. (1983). Indocyanine green was measured on a Shimadzu UV 200 S double beam spectrophotometer at a wavelength of 786 nm.

The following pharmacokinetic parameters of verapamil were calculated after intravenous and oral application of the drug: terminal phase half-life ( $t 1 / 2$ $\beta$ ) by linear regression analysis of the logarithmic values from the terminal linear slope of the plasma level curve;

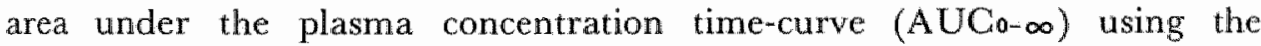
trapezoidal method and extrapolation to infinity by dividing last plasma concentration by $\beta$;

total clearance $(\mathrm{Cl})$ by dividing the intravenous dose by AUCio- $\infty$; apparent oral clearance $(\mathrm{Clo})$ by dividing the oral dose by $\mathrm{AUC}_{0-\infty}$; area volume of distribution $\left(\mathrm{V}_{\beta}\right)=\frac{\mathrm{Cl} \times \mathrm{t} / \mathrm{R} B}{\mathrm{Ln} 2}$

Cmax: maximum plasma concentration;

Tmax: time of occurrence of the maximum plasma concentration.

The pharmacokinetic parameters of indocyanine green ( $t 1 / 2, A U C 0-\infty$, $\mathrm{Cl}$, Volume of distribution $\mathrm{Vd}$ ) were calculated using an one-compartment model by linear regression analysis of the logarithmic values. Vd was calculated by dividing the dose by the apparent concentration at time 0 . 
Table 1. Pharmacokinetic parameters of indocyanine green after $25 \mathrm{mg}$ i.v. 4 normal subjects

\begin{tabular}{l|c|c|c}
\hline & rest & exercise & $p$ \\
\hline $\mathrm{t}^{1 / 2}(\mathrm{~min})$ & $2.8 \pm 0.3$ & $3.8 \pm 0.3$ & $>0.05$ \\
$\mathrm{AUC}\left(0-\infty\left(\mathrm{ng} \cdot \mathrm{ml}^{-1} \cdot \mathrm{min}\right)\right.$ & $23100 \pm 3300$ & $32600 \pm 1800$ & $<0.01$ \\
$\mathrm{Cl}\left(\mathrm{ml} . \mathrm{min}^{-1}\right)$ & $1156 \pm 177$ & $774 \pm 48$ & $<0.05$ \\
$\mathrm{~V}_{\mathbf{d}}(\mathrm{l})$ & $5.1 \pm 0.8$ & $4.3 \pm 0.2$ & $>0.1$ \\
\hline
\end{tabular}

Table 2. Plasma concentrations of verapamil after $0.13 \mathrm{mg} / \mathrm{kg}$ i.v. in 6 norm subjects

\begin{tabular}{c|c|c}
\hline \multirow{2}{*}{$\begin{array}{c}\text { Time (min) } \\
\text { after injection }\end{array}$} & rest day & \multicolumn{2}{|c}{ Verapamil (ng/ml) } \\
\cline { 2 - 3 } & $91.4 \pm 19.4$ & $115.2 \pm 30.8$ \\
\hline 30 & $88.1 \pm 22.7$ & $111.4 \pm 55.2$ \\
60 & $65.0 \pm 19.4$ & $43.8 \pm 20.9$ \\
90 & $30.5 \pm 13.4$ & $21.8 \pm 6.3$ \\
150 & $22.2 \pm 8.7$ & $18.7 \pm 6.7$ \\
210 & $13.6 \pm 5.3$ & $10.6 \pm 3.4$ \\
270 & $10.6 \pm 3.1$ & $8.6 \pm 2.4$ \\
330 & $7.5 \pm 1.8$ & $7.4 \pm 2.0$ \\
390 & $5.8 \pm 0.8$ & $6.5 \pm 1.4$ \\
450 & & \\
\hline
\end{tabular}

Table 3. Pharmacokinetic parameters of verapamil after i.v. injection in 6 no mal subjects

\begin{tabular}{l|r|r|c}
\hline & rest day & exercise day & $p$ \\
\hline $\mathrm{t} 1 / 2 \beta(\mathrm{min})$ & $161 \pm 23$ & $146 \pm 16$ & $>0.1$ \\
$\mathrm{AUC0}-\infty$ & & & \\
$\left(\mathrm{ng} \cdot \mathrm{ml}^{-1} \cdot \mathrm{min}\right)$ & $14880 \pm 3120$ & $14160 \pm 4140$ & $>0.4$ \\
$\mathrm{Cl}\left(\mathrm{ml} \cdot \mathrm{min}^{-1}\right)$ & $772 \pm 125$ & $862 \pm 128$ & $>0.2$ \\
$\mathrm{~V} \beta(\mathrm{I})$ & $198 \pm 53$ & $189 \pm 43$ & $>0.4$ \\
\hline
\end{tabular}


Results are expressed as mean \pm SEM. Within-group comparison of single values was made with Student's $t$-test for paired data. Differences between the rest and exercise days in the plasma level curves of verapamil and norverapamil as well as in blood pressure and heart rate were tested by the randomization test of Zerbe (1979).

\section{Results}

\section{Influence of physical exercise on the pharmacokinetics of indocyanine green}

Table 1 represents the pharmacokinetic parameters of indocyanine green during rest and exercise. As compared with the situation at rest, exercise significantly decreased the total clearance and the $\mathrm{AUCi}_{0-\infty}$ of indocyanine green. During exercise the total clearance was $30 \pm 7 \%$ lower than during the rest day.

\section{Pharmacokinetics after intravenous injection of verapamil}

The plasma verapamil levels after intravenous injection on the rest and the exercise days, respectively, are given in Table 2 . When compared by analysis of variance, the plasma concentrations on the two days did not differ $(p>0.15)$. On both days, norverapamil was not detectable in plasma. There were no significant differences between the rest and the exercise day in the pharmacokinetic parameters of verapamil (Table 3). The half-life of the terminal phase of the verapamil plasma levels was slightly shorter on the exercise day than on the rest day. The difference is, however, not statistically significant ( $p$ $>0.1)$.

Blood pressure in sitting position was $117 \pm 3 / 72 \pm 2 \mathrm{mmHg}$ on both study days before application of the drug. Heart rate was $73 \pm 5$ beats $/ \mathrm{min}$. The intravenous injection of verapamil did not alter these parameters $(p>0.1)$.

\section{Pharmacokinetics after oral administration of verapamil}

The plasma levels of verapamil and norverapamil after oral administration of $80 \mathrm{mg}$ of the parent drug are given in Table 4 . When tested by analysis of variance, the plasma levels of verapamil on the rest and exercise day did not differ $(p>0.3)$, nor was there any difference between the two days in the norverapamil concentrations $(p>0.2)$.

The pharmacokinetic parameters after oral application of verapamil are shown 
in Table 5. During the exercise day, the half-life of the terminal phase of $t$ plasma level curve was slightly lower as compared with the rest day. The $\mathrm{di}$ ference was, however, not statistically significant $(p>0.1)$. There were all no statistically significant differences between the two days in the other pha macokinetic parameters.

Before oral application of verapamil, blood pressure on both study days w $124 \pm 3 / 71 \pm 2 \mathrm{mmHg}$ and heart rate was $65 \pm 4$ beats $/ \mathrm{min}$. Oral application the calcium entry blocker did not alter blood pressure and heart rate $(p>0.1$

Table 4. Plasma concentrations of verapamil and norverapamil in 6 norm subjects after $80 \mathrm{mg}$ verapamil orally

\begin{tabular}{|c|c|c|c|c|}
\hline \multirow{2}{*}{$\begin{array}{l}\text { Time (min) } \\
\text { after oral } \\
\text { application }\end{array}$} & \multicolumn{2}{|c|}{ Verapamil (ng/ml) } & \multicolumn{2}{|c|}{ Norverapamil $(\mathrm{ng} / \mathrm{ml})$} \\
\hline & rest day & exercise day & rest day & exercise day \\
\hline 30 & $58.5 \pm 15.8$ & $85.4 \pm 46.4$ & $31.1 \pm$ & $36.1 \pm 16.1$ \\
\hline 90 & $44.0 \pm 7.4$ & $53.7 \pm 8.9$ & $44.6 \pm$ & $62.8 \pm 7.1$ \\
\hline 150 & $31.9 \pm 5.5$ & $34.5 \pm$ & $43.1 \pm$ & $49.6 \pm$ \\
\hline 210 & $22.1 \pm$ & $21.5 \pm$ & $38.0 \pm$ & $42.1 \pm$ \\
\hline 270 & $15.4 \pm 1.6$ & $13.7 \pm$ & $32.2 \pm$ & $33.7 \pm$ \\
\hline 330 & $12.1 \pm 2.0$ & $10.2 \pm$ & $28.1 \pm$ & $28.0 \pm$ \\
\hline 390 & $9.5 \pm$ & $7.8 \pm$ & $23.3 \pm$ & $23.0 \pm$ \\
\hline 450 & $8.3 \pm 1.6$ & $6.4 \pm$ & $22.1 \pm$ & $19.0 \pm$ \\
\hline
\end{tabular}

Table 5. Pharmacokinetic parameters of verapamil after oral administration , $80 \mathrm{mg}$ in 6 normal subjects

\begin{tabular}{l|r|r|l}
\hline & \multicolumn{1}{|c|}{ rest day } & exercise day & $p$ \\
\hline C max (ng/ml) & $66.9 \pm 13.1$ & $96.1 \pm 43.5$ & $>0.2$ \\
Tmax (min) & $60 \pm 13$ & $70 \pm 12.6$ & $>0.15$ \\
$\mathrm{t} / / 2 \beta(\mathrm{min})$ & $161 \pm 16$ & $139 \pm 14$ & $>0.10$ \\
$\mathrm{AUCl}-\infty\left(\mathrm{ng} \cdot \mathrm{ml}^{-1} . \mathrm{min}\right)$ & $13260 \pm 2040$ & $14040 \pm 3180$ & $>0.4$ \\
$\mathrm{Cll}\left(\mathrm{ml} \cdot \mathrm{min}^{-1}\right)$ & $6733 \pm 950$ & $7067 \pm 1300$ & $>0.4$ \\
\hline
\end{tabular}




\section{Discussion}

There are several reports on the pharmacokinetics of verapamil in normal subjects (Schomerius et al. 1976, Konke et al. 1979, Dominic et al. 1981, Eichelbaum et al. 1981, Mc Allister and Kirsten 1982, Kates 1983, Mooy et al. 1985). The pharmacokinetic parameters found in resting subjects in the present study are comparable with those reported by other authors. This is true for the terminal phase half-life of verapamil after intravenous injection of the drug, for the total clearance and for the volume of distribution. Furthermore, the maximum plasma concentration of verapamil after oral administration and its time of occurrence found in our study are similar to the data reported by other authors (Eichelbaum 1981, Mooy et al. 1985). As reported bij Mc Aluister and Kirsten (1982) and by Mooy et al. (1985), no norverapamil could be detected in plasma after a single intravenous dose of verapamil. However, after an oral dose of the calcium entry blocker the plasma concentrations of the metabolite were comparable with the levels of the parent drug.

The present study confirms the data of other investigators (Rowell et al. 1964, Swartz et al. 1974) who demonstrated a decrease of indocyanine green clearance during exercise. Rowerl et al. (1964) have shown that the indocyanine green clearance is a useful indicator of liver blood flow. Therefore, a decrease of indocyanine green clearance by $30 \%$ as found in our study certainly reflects a reduction of liver perfusion.

In our study, no influence of exercise on pharmacokinetic parameters of verapamil was found. There was a slight decrease of the terminal phase halflife of the verapamil plasma level curve during exercise, both after intravenous as well as after oral application of the drug. The difference between these data and the values measured on the rest days were, however, not statistically significant.

One might assume that a decrease of hepatic blood flow would enhance the half-life and reduce the total clearance of highly extracted drugs like verapamil (Wilkinson and SHAND 1975). The fall of the indocyanine green clearance during exercise as observed in our study was, however, rather small. The exercise protocol was chosen because it resembles usual daily activities. A decrease of verapamil clearance with a higher work load cannot be excluded.

In contrast to the present study with verapamil, Arends et al. (1985) found a decrease of the terminal phase half-life of the propranolol plasma level 
during submaximal exercise. The exercise protocol was similar as in the present study. The unexpected finding with propranolol could be due to a decrease of the volume of distribution of the beta-receptor blocking agent, With little or no change of total clearance, this would result in a fall of half-life. A decrease of the volume of distribution of propranolol during exercise could be the consequence of a displacement of the beta-blocker from its site of action by high noradrenaline concentrations, as has been suggested by Hurwitz ef al. (1983). This assumption would explain why verapamil behaves in a different way.

Taken together, our study does not demonstrate alterations of the phar. macokinetics of verapamil by prolonged submaximal exercise. Therefore there is no need for dose adjustment in patients undergoing regular exercise. 


\section{References}

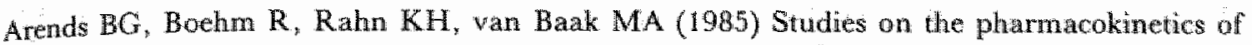
propranolol during exercise. Naumyn-Schmiedeberg's Arch Pharmacol 329 Suppl: R98

Dominic JA, Bourne DWA, Tan TG, Kirsten EB, McAllister RG (1981) The pharmacology of verapamil. III. Pharmacokinetics in normal subjects after intravenous drug administration. Journal of Cardiovascular Pharmacol 3: 25-38.

Eichelbaum M, Somogyi A, von Unruh GE, Dengler HJ (1981) Simultaneous determination of the intrawenous and oral pharmacokinetic parameters of $D, L$-werapamil using stable isotopelabelled verapamil. Eur J Clin Pharmacol 19:133-137

Ekelund LG, Ekelund C, Rossner S (1982) Antihypertensive effects at rest and during exercise of a calcium blocker, nifedipine, alone and in combination with metoprolol. Acta Med Scand 212: $71-75$

Evans GH, Shand DG (1973) Disposition of propranolol VI. Clin Pharmacol Ther 14: 494-500

Franz IW, Wiewel D (1984) Antihypertensive effects on blood pressure at rest and during exercise of calcium antagonists, beta-receptor blockers, and their combination in hypertensive patients. Journal of Cardiovascular Pharmacology 6: \$1037-\$1042

Hamann SR, Blouin RA, McAlister Jr RG (1984) Clinical pharmacokinetics of verapamil. Clinical Pharmacokinetics 9: 26-41.

Hurwitz GA, Webb JG, Walle T, Bai SA, Daniell HB, Gourley L, Boyd Loadholt C, Gaffney TE (1983) Exercise-induced increments in plasma levels of propranolol and noradrenaline. Brit J of Clin Pharmacol 16: 599-608

Kates RE (1983) Calcium antagonists: pharmacokinetic properties. Drugs 25: 113-124

Koike Y, Shimamura K, Shudo I, Saito H (1979) Pharmacokinetics of verapamil in man. Res Commun Chem Pathol Pharmacol 24: 37-47

Lund-Johansen $\mathbb{P}$ (1984) Hemodynamic effects of verapamil in essential hypertension at rest: and during exercise. Acta Med Scand Suppl 681: 109-115

McAllister RG, Kirsten EB (1982) The phamacology of verapamil. IV. Kinetic and dymamic effects after single intravenous and orall doses. Clin Pharmacol Ther 31: 418-426

Mooy J, Schols M, van Baak M, van Hooff M, Muytjens A, Rahn KH (1985) Pharmacokinetics of verapamil in patients with renal failure. Eur J Clin Pharmacol 28: 405-410.

Rowell LB, Blackmon JR, Bruce RA (1964) Indocyanine green clearance and estimated hepatic blood flow during mild to maximal exercise in upright man. J Clin Invest 43: 1677-1690

Schomerus M, Spiegelhalder B, Stieren B, Eichelbaum M (1976) Physiological disposition of verapamil in man. Cardiovasc Res 10: 605-612

Stein DT, Lowenthal DT, Porter RS, Falkner B, Bravo EL, Hare ThW (1984) Effects of: nifedipine and verapamil on isometric and dynamic exercise in normal subjects. American $J$ of Card 54: 386-389 
Svennson CK, Edwards DJ, Mauriello PM, Barde SH, Foster AC, Lanc RA, Middleton I Lalka D (1983) Effect of food on hepatic blood llow: Implications in the "food effect phenomenon. Clin Pharmacol Ther 34: $16-323$

Swartz RD, Sidell FR, Cucinell SA (1974) Effects of physical stress on the diposition of drui diminated by the live in man. $J$ of Pharm and Exper Therapeutics 188: 1-7

Sweeney GD (1981) Drugs - some basic concepts. Med Sci Sports Exercise 13: 247-251

Wilkinson GR, Shand DG (1975) A physiological approach to hepatic drug clearance. Cli Pharmacol Ther $18: 377-390$

Zerbe GO (1979) Randomization analysis of randomized block design extended to growth an response curves. Commun Stat Theor Methodol A8[2]: 191-205 


\section{Chapter 5}

\section{A comparison of the effects of verapamil and propranolol on submaximal exercise tolerance in patients with essential hypertension*}

J. Mooy ", R. Boehm", H. Petri², J. v. Kemenade ${ }^{2}$ and K.H. Rahn".

1 Department of Internal Medicine, Division of Nephrology, Hypertension, and Clinical Pharmacology,

2 and Department of Pharmacology,

University of Limburg, Maastricht, The Netherlands

* Submitted for publication. 


\section{Summary}

In a single blind, placebo controlied, cross-over study, the effects of verapamil ( $446 \pm 34 \mathrm{mg} / \mathrm{day})$ and propranolol $(166 \pm 22 \mathrm{mg} / \mathrm{day})$ on endurance time during submaximal exercise were compared in 7 patients with essential hypertension. The drugs were given in randomized order. Each active drug period was preceded by a placebo phase. Endurance tests were performed during both placebo periods as well as during treatment with verapamil and propranolol using bicycle ergometry. Plasma concentrations of verapamil and propranolol were measured immediately before each endurance test using highperformance liquid chromatography. Both drugs were equally effective in decreasing resting blood pressure. During exercise verapamil reduced systolic and diastolic blood pressure, while propranolol decreased systolic blood pressure and tended to increase diastolic blood pressure. Both drugs reduced exercise heart rate, the effect of propranolol being more pronounced. With placebo endurance time during exercise was $55 \pm 13 \mathrm{~min}$ and with propranolol $32 \pm 9 \mathrm{~min}(p<0.02)$. Verapamil had no influence on endurance time. Verapamil plasma levels before exercise were $165 \pm 48 \mathrm{ng} / \mathrm{ml}$, and propranolol plasma levels $65 \pm 15 \mathrm{ng} / \mathrm{ml}$. The study demonstrates that in contrast to propranolol verapamil has no influence on endurance time during submaximal exercise in hypertensive patients.

\section{Introduction}

Many studies have shown that administration of beta-adrenoceptor blocking agents reduces maximal and submaximal exercise tolerance in normotensive and hypertensive subjects (Franciosa et al. 1980, Lundborg et al. 1981, SABLE et al. 1982, Fellenius 1983, Wilcox et al. 1984, van BaAk et al. 1985).

Recently, calcium antagonists have been introduced for the treatment of hypertension. Although there are some studies on the antihypertensive action of calcium antagonists during exercise (Lund-JoHANSEN 1984, STEIN et al. 1984), the effects of these drugs on exercise tolerance have not been studied so far. We, therefore, started a study to compare the influence of verapamil and propranolol on endurance time during submaximal work in patients with essential hypertension. 


\section{Subjects and methods}

Seven male patients, age $27-57$ years, with mild to moderate essential hypertension were studied. During observation in the outpatient clinic without treatment, the patients had supine blood pressure values ranging from $140 / 90$ - 170/105 mmHg. Secondary hypertension had been excluded by history, physical examination, appropriate laboratory tests and by intravenous pyelography. All patients had given informed consent. The protocol of the study was approved by the Ethical Committee of The University of Limburg Medical School. Prior to the study during an observation period in the outpatient clinic, the doses of propranolol and verapamil were determined which lowered supine blood pressure to levels below $140 / 90 \mathrm{mmHg}$.

The study was of single blind cross-over design. At first, all antihypertensive drugs were withdrawn for at least 4 weeks. Then, the patients received placebo for a total of 5 weeks. After 2 weeks placebo, the work load during bicycle ergometry which increased heart rate to 150 beats $/ \mathrm{min}$ (W150) was determined. After the first placebo period, the patients received propranolol and verapamil in randomized order for 4 weeks each with another 3 weeks' placebo period in between. During the active drug periods treatment was started with the doses of propranolol and verapamil, respectively, which had lowered supine blood pressure to $<140 / 90 \mathrm{mmHg}$ in the outpatient clinic. If during the first two weeks of the active drug periods these doses did not decrease supine systolic blood pressure by $\geq 10 \mathrm{mmHg}$ as compared with the preceding placebo period, the doses of propranolol and verapamil were enhanced. Such an increase was necessary in 4 patients during the verapamil period and in one patient during the propranolol phase. The doses given during the third and fourth week of the active drug periods were $166 \pm 22 \mathrm{mg} / \mathrm{day}$ for propranolol and $446 \pm 34 \mathrm{mg} /$ day for verapamil. The total daily doses were equally divided into 3 single doses which were given at 8 o'clock a.m., 3 o'clock p.m. and $10 o^{\prime}$ clock p.m. All measurements were performed 2-4 hrs after a single dose. Throughout the study no drugs other than propranolol and verapamil were given.

Endurance tests on a bicycle ergometer at the predetermined W150 were performed once in each placebo period as well as twice in each active drug phase. During the tests, the patients exercised for periods of $30 \mathrm{~min}$ each with $10 \mathrm{~min}$ rest in between until they became exhausted. The interval between the endurance tests was at least 1 week. 
During the study, blood pressure and heart rate were measured at weekly intervals after 30 min rest in supine position and again after 5 min standing. Blood pressure and heart rate were also determined during the endurance tests, at 30 and $60 \mathrm{~min}$ and at exhaustion. Immediately before the endurance tests, venous blood samples were drawn for measuring the plasma levels of propranolol as well as of verapamil and of its metabolite norverapamil.

Blood pressure at rest was always measured by means of an automatic recorder (Dinamap, Applied Medical Research Corporation, Tampa, U.S.A.). During exercise, blood pressure was determined by means of a mercury manometer. The point of muffling of the Korotkoff sounds (phase IV) was read as the diastolic value.

Plasma verapamil and norverapamil levels were determined by means of high-performance liquid chromatography (HPLC) with fluorometric detection, as described earlier (Mooy et al. 1985).

Propranolol was determined by a similar technique. For this, the drug was extracted from plasma into hexane: pentanol (98.5: 1.5) after metoprolol had been added as internal standard. The organic phase was re-extracted with $0.01 \mathrm{~N} \mathrm{H}_{2} \mathrm{SO}_{4}$. An aliquot of the $\mathrm{H}_{2} \mathrm{SO}_{4}$-phase was subjected to $\mathrm{HPLC}$ using a microsphere C18 column (Chrompack, Middelburg, The Netherlands). Acetonitrile: methanol: $0.01 \mathrm{~N} \mathrm{HClO}_{4}(71: 25: 4)$ was used as the eluent. The $\mathrm{pH}$ of the eluent was brought to 6.0 using $\mathrm{H}_{3} \mathrm{PO}_{4}$. For fluorometric detection, the excitation wavelength was $208 \mathrm{~nm}$ and the emission filter was set at 320 $\mathrm{nm}$. The detection limit of this procedure is $1 \mathrm{ng}$ propranolol $/ \mathrm{ml}$ plasma. The interassay coefficient of variation is $4 \%$.

Results are expressed as mean \pm SEM from 7 patients. Statistical analysis was performed using Student's t-test for paired data.

\section{Results}

\section{Effects of verapamil and propranolol on blood pressure and heart rate at rest.}

Blood pressure and heart rate data obtained at the end of the last but one week of each experimental period did not differ from the values measured at the end of the respective study period $(p>0.3$. Therefore, the mean values of the data obtained during the last 2 weeks of each period were calculated and used for further analysis. 
The supine blood pressure and heart rate values of each study period are given in Table 1. During the placebo phases, the blood pressure of the patients was somewhat lower than during observation in the outpatient clinic prior to antihypertensive treatment. Systolic and diastolic blood pressure were identical in both placebo periods. Both verapamil and propranolol decreased supine blood pressure to an almost identical extent. Both drugs also decreased standing blood pressure values $(p<0.01)$. Verapamil did not change heart rate in supine and standing position, whereas propranolol caused a significant reduction of this parameter.

2. Effects of verapamil and propranolol on blood pressure and heart rate during submaximal exercise.

As expected, blood pressure and heart rate rose during bicycle ergometry. Blood pressure and heart rate values determined after $30 \mathrm{~min}$ exercise did not differ from the data measured after $60 \mathrm{~min}$ and at exhaustion. Therefore, only the data obtained at the first measurements during exercise are given in Tables 2-4.

Table 1. Effects of verapamil and propranollol on blood pressure $(\mathrm{mmHg})$ and heart rate (beats/min) at supine rest $(n=7)$

\begin{tabular}{l|c|c|c|c|c|c}
\hline & $\begin{array}{c}\text { Placebo } \\
\text { (before } \\
\text { vera- } \\
\text { pamil) }\end{array}$ & $\begin{array}{c}\text { Vera- } \\
\text { pamil }\end{array}$ & $p$ & $\begin{array}{c}\text { Placebo } \\
\text { (before } \\
\text { propra- } \\
\text { nolol) }\end{array}$ & $\begin{array}{c}\text { Propra- } \\
\text { nolol }\end{array}$ & $p$ \\
\hline $\begin{array}{l}\text { systolic blood } \\
\text { pressure } \\
\text { (mmHg) }\end{array}$ & $153 \pm 3$ & $140 \pm 6$ & $<0.05$ & $153 \pm 4$ & $140 \pm 4$ & $<0.01$ \\
$\begin{array}{l}\text { diastolic blood } \\
\text { pressure } \\
\text { (mmHg) }\end{array}$ & $89 \pm 4$ & $80 \pm 4$ & $<0.05$ & $90 \pm 4$ & $80 \pm 4$ & $<0.01$ \\
$\begin{array}{l}\text { mean arterial } \\
\text { pressure } \\
\text { (mmHg) } \\
\text { heart rate } \\
\text { (beats/min) }\end{array}$ & $111 \pm 3$ & $100 \pm 5$ & $<0.05$ & $111 \pm 4$ & $100 \pm 3$ & $<0.01$ \\
\hline
\end{tabular}


Table 2. Effects of verapamil and propranolol on systolic blood pressure (mmHg) during submaximal exercise

\begin{tabular}{c|c|c|c|c}
\hline Patients & $\begin{array}{c}\text { Placebo } \\
\text { (before } \\
\text { verapamil) }\end{array}$ & Verapamil & $\begin{array}{c}\text { Placebo } \\
\text { (before } \\
\text { propranolol) }\end{array}$ & Propranolol \\
\hline So. & 245 & 225 & 235 & 220 \\
St. & 205 & 194 & 197 & 180 \\
Ve. & 212 & 204 & 215 & 192 \\
Mo. & 185 & 178 & 195 & 190 \\
Ov. & 210 & 205 & 212 & 190 \\
Mi. & 202 & 208 & 175 & 163 \\
He. & 197 & 169 & 212 & 188 \\
\hline mean \pm SEM & $208 \pm 7$ & $198 \pm 7$ & $206 \pm 7$ & $189 \pm 6$ \\
\hline$p$ & \multicolumn{2}{c}{$<0.05$} & \multicolumn{2}{c}{$<0.01$} \\
\hline
\end{tabular}

Table 3. Effects of verapamil and propranolol on diastolic blood pressure $(\mathrm{mmHg})$ during submaximal exercise

\begin{tabular}{c|c|c|c|c}
\hline Patients & $\begin{array}{c}\text { Placebo } \\
\text { (before } \\
\text { verapamil) }\end{array}$ & Verapamil & $\begin{array}{r}\text { Placebo } \\
\text { (before } \\
\text { propranolol) }\end{array}$ & Propranolol \\
\hline So. & 120 & 95 & 122 & 122 \\
St. & 85 & 70 & 87 & 89 \\
Ve. & 115 & 90 & 105 & 107 \\
Mo. & 75 & 77 & 80 & 90 \\
Ov. & 105 & 110 & 105 & 105 \\
Mi. & 94 & 80 & 80 & 85 \\
He. & 82 & 65 & 70 & 90 \\
\hline mean \pm SEM & $97 \pm 7$ & $84 \pm 6$ & $93 \pm 7$ & $98 \pm 5$ \\
\hline & \multicolumn{2}{c}{$<0.02$} & \multicolumn{2}{c}{$<0.05$} \\
\hline
\end{tabular}


In the two placebo periods, systolic and diastolic blood pressure as well as heart rate during exercise were similar. Both verapamil and propranolol decreased systolic blood pressure during ergometer exercise (Table 2). The effect of propranolol was somewhat more pronounced, but the difference between the 2 drugs was not statistically significant $(p>0.05)$. The diastolic blood pressure measured during exercise was reduced by verapamil, whereas with propranolol this parameter tended to increase (Table 3). As compared with placebo, both verapamil and propranolol decreased heart rate during ex. ercise, the effect of propranolol being clearly more pronounced (Table 4).

\section{Effects of verapamil and propranolol on endurance time}

Fig. 1 represents the influence of verapamil and propranolol on endurance time. There was no difference between the placebo periods in the endurance time at W150. As compared with the preceding placebo period, propranolol significantly reduced the endurance time from $55 \pm 13$ to $32 \pm 9 \mathrm{~min}(p$ $<0.02$ ). During treatment with propranolol the endurance time was also lower than during the placebo period preceding verapamil treatment $(p<0.02)$. In

Table 4. Effects of verapamil and propranolol on heart rate (beats/min) during submaximal exercise

\begin{tabular}{c|c|c|c|c}
\hline Patients & $\begin{array}{c}\text { Placebo } \\
\text { (before } \\
\text { verapamil) }\end{array}$ & Verapamil & $\begin{array}{c}\text { Placebo } \\
\text { (before } \\
\text { propranolol) }\end{array}$ & Propranolol \\
\hline So. & 156 & 135 & 153 & 118 \\
St. & 162 & 138 & 156 & 122 \\
Ve. & 163 & 150 & 166 & 123 \\
Mo. & 151 & 139 & 145 & 109 \\
Ov. & 178 & 174 & 169 & 126 \\
Mi. & 150 & 138 & 160 & 119 \\
He. & 170 & 142 & 188 & 152 \\
\hline mean \pm SEM & $161 \pm 4$ & $145 \pm 5$ & $162 \pm 5$ & $124 \pm 5$ \\
\hline$p$ & $<0.01$ & \multicolumn{2}{c}{$<0.001$} \\
\hline
\end{tabular}


contrast, verapamil had no influence on endurance time. During treatment with verapamil, endurance time was $46 \pm 13 \mathrm{~min}$, which did not differ from the values obtained in the placebo period $(p>0.2)$.

\section{Plasma concentrations of verapamil, norverapamil and propranolol.}

During treatment with verapamil, the plasma concentrations of the calcium entry blocker determined immediately before the exercise tests averaged to 165 $\pm 48 \mathrm{ng} / \mathrm{ml}$, with norverapamil concentrations of $151 \pm 34 \mathrm{ng} / \mathrm{ml}$. The plasma propranolol concentrations during treatment with the beta-receptor blocking agent amounted to $65 \pm 15 \mathrm{ng} / \mathrm{ml}$.

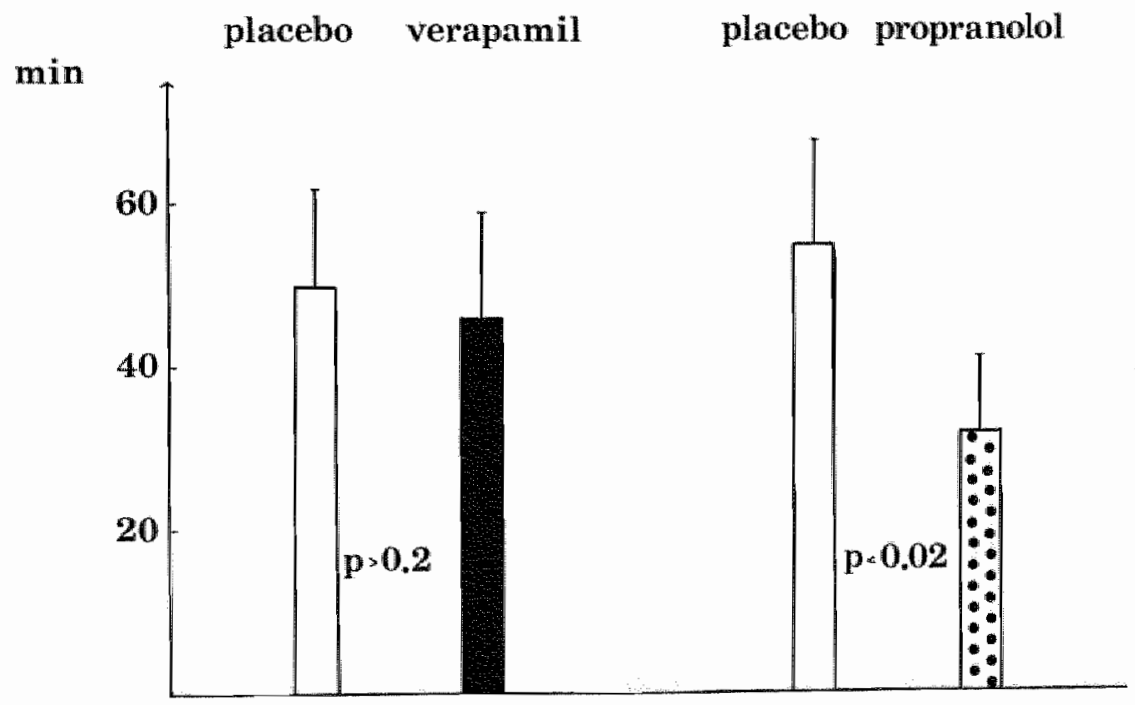

Fig. 1. Influence of verapamil and propranolol on endurance time. 


\section{Discussion}

In the present study in patients with essential hypertension, a similar antihypertensive effect of verapamil and propranolol was found at rest. This is in agreement with the results of several other investigators (FRISCHMAN et al. 1982, Doyle 1983, Leonetti et al. 1984, Halperin et al. 1984, Hornung et al. 1984). As found in these studies, the dose of verapamil which had to be given to obtain a hypotensive effect was rather high as compared with the doses usually given in patients with angina pectoris.

During bicycle ergometry at a submaximal work load, verapamil decreased both systolic and diastolic blood pressure, the effect on diastolic blood pressure being more pronounced. Other authors, too, have demonstrated a decrease of systolic and diastolic blood pressure during exercise by treatment with verapamil (Hornung et al. 1984, Lund-JoHANSEN 1984).

In our study, propranolol reduced systolic blood pressure during exercise. In contrast, diastolic blood pressure measured during bicycle ergometry tended to increase during treatment with the beta-receptor blocking agent. There are conflicting reports concerning the effect of propranolol on diastolic blood pressure during exercise. McLeod et al. (1983) and Mhller et al. (1983) found an increase of diastolic blood pressure during treatment with propranolol, whereas in other studies no influence of the beta-blocker on diastolic blood pressure was described (Sable et al. 1982, Sklar et al. 1982). Hornung et al. (1984) reported a reduction of diastolic blood pressure during exercise in hypertensives treated with propranolol. These discrepancies could result from the use of different techniques for determining blood pressure during exercise. Hornung et al. (1984) measured blood pressure directly by means of arterial cannulation, while in the other studies indirect methods were used. In view of the difficulties to deternine the point of muffling of the Korotkoff sounds during dynamic exercise, the indirect method seems less reliable.

As other authors we found that verapamil has no influence on heart rate at rest (LUND-JOHANSEN 1984, LeONETrr et al. 1984) but slightly decreases heart rate during exercise (Lund-Johansen 1984, Hornung et al. 1984, Stein et al. 1984). This could be due to the direct effect of the drug on the myocardium. As also shown by other investigators (Hornung et al. 1984) the influence of propranolol on heart rate during exercise was much more pronounced. 
Whereas verapamil and propranolol had similar effects on resting blood pressure and on systolic blood pressure during exercise in our study, both drugs considerably differed in the influence on endurance time. As other authors (Lundborg et all 1981, Wilcox et al. 1984) we found that chronic administration of propranolol reduces physical performance during submaximal work. In contrast, verapamil had no influence on endurance time.

The reduction of endurance time by propranolol could be due to the decrease of cardiac output caused by this beta-receptor blocking agent. The effect of propranolol on cardiac output is most pronounced during physical exercise (Epstein et al. 1965). This could seriously decrease blood supply to the working muscles and, thereby, diminish work capacity. Unlike propranolol, the calcium entry blocker verapamil does not decrease cardiac output in hypertensive patients. This is true for measurements performed at rest as well as during physical exercise (LUND-JoHANSEN 1984). Thus, the differences in the influence of verapamil and propranolol on endurance time during bicycle ergometry could be due to different haemodynamic effects.

Taken together, both verapamil and propranolol effectively decrease blood pressure in resting and exercising patients with essential hypertension. Treatment with verapamil could be an alternative for physically active hypertensive patients who complain of muscular fatigue during treatment with betareceptor blocking agents. 


\section{References}

van Baak M, Jennen W, Verstappen FTJ (1985) Maximal aerobic power and blood pressure in normotensiwe subjects after acute and chronic administration of metoprolol. Eur J Clin Phar macol 28: $143-148$

Doyle A (1993) Comparison of beta-adrenoceptor blockers and calcium antagonists in hypertension. Hypertension 5 Suppl III: 103-108

Epstein SE, Robinson BF, Kahler RL, Braunwald E (1965) Effects of beta-adrenergic blockade on the cardiac response to maximal and submaximal exercise in man. Journal of Clinical In vestigation 44 : $1745-1753$

Fellenius E (1983) Muscle fatigue and beta-blockers - A rewiew. Int J Sports Med 4: 1-8

Franciosa JA, Johnson SM, Tobian LJ (1980) Exercise performance in mildly hypertensive patients. Chest 78: 291-299

Frishman WH, Klein NA, Klein Ph, Strom JA, Tawi R, Strair R, Wong B, Roth S, Lejemtel TH, Pollack $\$$, Sonnenblick EH (1982) Comparison of oral propranolol and verapamil for combined systemic hypertension and angina pectoris - a placebo-controlled double-blind randomized cross-over trial. Amer J Cardiol 50: 1164-1172

Halperin AK, Gross KM, Rogers JF, Cubeddu LX (1984) Verapamil and propranolol in essential hypertension. Clinical Pharmacology and Therapeutics 36: 750-758

Hornung RS, Jones RI, Gould BA, Sonecha T, Raftery EB (1984) Propranolol versuss verapamil for the treatment of essential hypertension. American Heart Journal 108: 554-560

Leonetti $G$, Pasotti $C$, Ferrari $G$, Zanchetti A (1984) Verapamil and propranolol: a comparison of two antihypertensive agents. Acta Med Scandinavica Suppl 681: 137-141

Lund-Johansen P (1984) Hemodynamic effects of verapamil in essential hypertension at rest. and during exercise. Acta Medica Scand Suppl 681: 109-115

Lundborg P, Astroem H, Bengtsson C, Fellenius E, won Schenck H, Svensson L, Smith U (1981) Effect of beta-adrenoceptor blockade on exercise performance and metabolism. Clinical Science 61: 299-305

McLeod AA, Brown JE, Kitchel BB, Sedor FA, Kuhn DC, Sanders Williams $\mathbb{R}$, Shand DG (1984) Hemodynamic and metabolic responses to exercise after alpha, beta, and nonselective beta-adrenoceptor blockade in man. Am J of Med 76 (2A): 97-101

Miller AJ, Kaplan BM, Upton MT, Grais IM, Abrams DL (1983) Treadmill exercise testing in hypertensive patients treated with hydrochlorothiazide and beta-blocking drugs. JAMA 250: $67-70$

Mooy, I" Schols M, van Baak M, van Hoof M, Muytjens A, Rahn KH (1985) Pharmacokinetics of verapamil in patients with renal failure. Eur J Clin Pharmacol 28: 405-410

Sable DL, Brammell HL, Sheehan MW, Nies AS, Gerber J, Horwitz LD (1982) Attenuation of exercise conditioning by beta-adrenergic blockade. Circulation 65: 679-684 
Sklar J Jlohnston GD, Overlie P, Gerber JG, Brammell HL, Gal J. Wies AS (1982) The etrects of a cardioselective (metoprolol) and a nonselective (propramolol) beta-adrenergic blocker on the response to dynamic exercise in normal men. Circulation 65: 894-899

Stein DT, Lowenthal DT, Porter RS, Falkner B, Bravo EL, Hare ThW (1984) Effects of nifedipine and werapamil on isometric and dynamic exercise in mormal subjects. American Journal of Cardiology $54: 386-389$

Whlcox RG, Bennett T, MacDonald JA, Herbert M, Skene AM (1984) The effects of acute or chronic ingestion of propranolol or metoprolol on the physiological responses to prolonged, submaximal exercise in hypertensive men. Brit J Cin Pharmacol 17: 273-281 


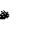




\section{Chapter 6}

General discussion and summary 
Calcium antagonists are a group of drugs with very interesting properties. They have particularly important aspects concerning the treatment of hypertension. Verapamil is the oldest representative of the group of calcium antagonists. Although verapamil was originally developed as a coronary vasodilating agent (HAAs and HAERTFELDER 1962), it appeared soon that the drug had a hypotensive action, too. FleGKenstein has the great merit to have elucidated the mode of action of verapamil and other calcium entry blockers. He launched the concept of "calcium antagonism" (FLeakenstern 1971). Later, other drugs with the same pharmacological properties have been developed. Although verapamil is used as a coronary vasodilator since many years, it has been given for the treatment of hypertension only recently. Nowadays, the antihypertensive effect of verapamil has clearly been established (DOYLE 1985). The primary mode of the antihypertensive action of this drug is lowering of the peripheral resistance (LUND-JoHANSEN 1984). Verapamil can now be considered as the first-choice drug for some groups of hypertensive patients, especially patients with broncho-obstructive disease and older patients (BueHLER et al. 1982).

Many studies have already been published about the pharmacological properties of verapamil (Singh et al. 1978, Nayler and Horowitz 1983, HamanN et al. 1984). However, there are no or only a few data available in the literature concerning some important aspects of the antihypertensive action of verapamil. Therefore, we decided to study the following aspects.

\section{Pharmacokinetics of verapamil in renal failure (chapter 2).}

Hypertension is a frequent symptom of kidney disease. Therefore, it is frequently necessary to give antihypertensive drugs to patients with renal failure. Because of particular reasons, e.g. age, it might be advisable to treat some of these patients with calcium blocking agents, especially verapamil. However, renal insufficiency can affect the pharmacokinetics of drugs in several ways (MAKER 1984). It can influence resorption, plasma protein binding, distribution in the body, metabolism and excretion. Also the disposition of drugs which are mainly metabolized by the liver, can be affected by uremia (Reidenberg 1977, Cutler et al. 1983, Patterson et al. 1984).

Little is known about the pharmacokinetics of verapamil in renal failure. KEEFE et al. (1981) found no difference in the plasma protein binding of verapamil between normal subjects and patients with renal failure. 
We studied the pharmacokinetics of verapamil in patients with terminal renal failure and in control subjects after one single intravenous dose, after a single oral dose and after a 5 days" period of oral treatment. In our study we found no difference between patients with renal failure and control subjects in the half-life, volume of distribution, bioavailability and the total body clearance. Hemodialysis did not significantly influence the verapamil plasma level curve obtained after intravenous injection. The amount of the drug eliminated by the artificial kidney was very low in comparison with the total clearance. We, therefore, conclude from this study that there is no need to adjust the cose of verapamil in patients with terminal renal failure and in patients undergoing hemodialysis.

\section{Drug interactions with verapamil (chapter 3).}

Verapamil is now frequently used for hypertension and given together with other drugs. Verapamil is highly metabolized by the liver (Kates 1983, HAMANN et al. 1984). Factors which alter liver function could therefore change the clearance of this drug. Cimetidine inhibits the oxydative drug metabolism by the liver and diminishes liver blood flow (FeELy et al. 1981, Sedman 1984), In contrast, rifampicin is a strong inductor of the hepatic drug metabolizing enzymes (BACIEwicz et al. 1984). Isoniazid, too, can possibly influence the pharmacokinetics of other drugs (Engelhard et al. 1984). Several drug interactions with cimetidine and rifampicin have been described (SEDMAN 1984, BAciewicz et al. 1984).

Therefore, we decided to study the influence of cimetidine, rifampicin and other drugs for tuberculosis on the pharmacokinetics of verapamil. In our study no influence of cimetidine on the disposition of verapamil was found.

Conflicting reports on the influence of cimetidine on the pharmacokinetics of verapamil have been published (WINo et al. 1983, Smitu et al. 1984, ChoMrno Lor et al. 1985). However, in view of the published data and our results it can be concluded that with normal doses of cimeticline there is little or no influence of this drug on the metabolism of verapamil. Therefore, there is no need to adjust the dose of the calcium antagonist in patients receiving cimetidine.

On the other hand, antituberculosis drugs had a great influence on the pharmacokinetics of verapamil. It was found that they strongly reduced the bioavailability of oral verapamil. The same result was found in two patients with a monotherapy of rifampicin. After discontinuation of rifampicin, plasma 
levels of verapamil were comparable with the results in control subjects. This observation suggests that the low bioavailability of verapamill after oral administration has been caused by rifampicin. A contribution of isoniazid and/or ethambutol, however, cannot be excluded. As can be expected for a drug with a high hepatic clearance (WILKInson and SHAND 1975), there was little or no change of the pharmacokinetics of verapamil after intravenous injection of the calcium antagonist in patients receiving rifampicin.

Probably, the combination verapamil-rifampicin will not frequently be given. However, in our department one patient was treated with verapamil and rifampicin together. The dose of verapamil given was $80 \mathrm{mg}$ t.i.d.. In this patient extremely low levels of the calcium antagonist were found. From this observation and the results of our study it may be concluded that in patients receiving rifampicin the oral dose of verapamil has to be increased in order to obtain therapeutic plasma llevels.

\section{Influence of prolonged submaximal exercise on the pharmacokinetics of verapamil in man (chapter 4)}

There are a lot of data about the pharmacokinetics of verapamil at rest (KATEs 1983, Hamann et al. 1984). However, exercise may influence the pharmacokinetics of drugs in several ways. During exercise, blood flow through the intestine and the liver decreases (Rowell et al. 1964, Swartz et al. 1974). This can influence both intestinal absorption and hepatic clearance of drugs. Other pharmacokinetic parameters which can change during exercise are the volume of distribution (SWEENEY et al. 1981) and the plasma protein binding (Evans et al. 1973).

Exercise is for many patients a more common daily activity than rest. However, little is known about the influence of exercise on the pharmacokinetics of drugs. Recently, Arends et al. (1985) have demonstrated that the half-life of the beta-receptor blocking agent propranolol decreases during prolonged submaximal exercise. The pharmacokinetics of verapamil resemble those of propranolol. Thus, it seemed possible that as with propranolol, the kinetics of verapamil are altered by physical exercise. Therefore, a study was started to test this possibility.

The exercise protocol was similar as in the propranolol study.

However, no influence of exercise on the pharmacokinetics of verapamil was found. One might assume that the decrease of hepatic blood flow would enhance the half-life and reduce the total clearance of drugs like verapamil (WILKINSON and SHAND 1975). However, the fall of indocyanine green 
clearance was relatively small in our study. The exercise protocol was chosen because it resembles daily activities. The decrease of verapamil clearance with a more extreme work load cannot be excluded.

The results of the study with propranolol (ARENDS et al. 1985) may have consequences for patients undergoing regular exercise and receiving the betareceptor blocking agent. As can be concluded from our study, there is, however, no need for dose adjustment of verapamil in patients performing regular exercise.

\section{A comparison of the effects of verapamil and propranolol on submaximal exercise tolerance in patients with essential hypertension (chapter 5).}

Many studies have demonstrated that treatment with beta-adrenoceptor blocking agents reduce exercise tolerance during maximal work. Submaximal work is probably a more adequate exercise test because it resembles daily activities. There are much less data about the effect of beta-blockers on endurance time during submaximal work (Fellenius 1983, VAN BAAK et al. 1985) The influence of beta-receptor blocking agents on exercise performance can be a great disadvantage for patients who perform regular physical activities. There are several possibilities for explaining this effect of beta-receptor blocking agents. One of them is the decreased cardiac output caused by these drugs, which is most pronounced during exercise.

Verapamil does not reduce cardiac output at rest and during exercise (LUNDJOHANSEN 1984).

However, there are so far no data available about the effect of verapamil on exercise tolerance during submaximal work. Therefore, we designed a study to compare the effects of propranolol and verapamil on endurance time during submaximal exercise in patients with essential hypertension. Prior to the study the doses of both drugs which lowered blood pressure to values lower than 140/90 $\mathrm{mmHg}$ were determined. During the study in some patients these doses of verapamil or propranolol had to be enhanced to achieve a decrease of systolic blood pressure by $\geq 10 \mathrm{~mm} \mathrm{Hg}$ as compared with placebo.

Exercise tests were performed with a predetermined work load.

Propranolol and verapamil had similar effects on blood pressure at rest and on systolic blood pressure during exercise.

Propranolol reduced endurance time by $42 \%$ as compared with placebo. In contrast, verapamil had no influence on endurance time.

The reason for this different effect of propranolol and verapamil on endurance time during submaximal exercise has to be clarified. 
However, this result can be important for hypertensive patients with complaints of fatigue during therapy with beta-receptor blocking drugs. For these patients verapamil may be an attractive alternative. 


\section{References}

Arends BG, Boehm R, Rahn KH, van Baak MA (1985) Studies on the pharmacokinetics of propranold during exercise. Naunyn-Schmiedeberg's Archives of Pharmacology 329: R98

wan Baak M, Jennen W, Verstappen FTJ (1985) Maximal aerobic power and blood pressure in normotensive subjects after acute and chronic administration of metoprolol. Eur J Clin Pharmacol 28: $143-148$

Baciewicz AM, Self TH (1984) Rifampin drug interactions. Arch Int Med 144: 1667-1671

Buchler FR, Hulthen $L_{\alpha}$, Kiowski $W$, Mueller FB, Bolli P (1982) The place of the callium antagonist verapamil in antihypertensive therapy. J Cardiovase Pharmacol 4: S350-\$357

Cho Ming Loi, Rollins DE, Dukes GE, Peat MA (1985) Effect of cimetidine and verapamil disposition. Clin Pharmacol Ther 37: 654-657

Cutler RE, Krichman KH, Blatr AD (1983) Pharmacokinetics of drugs and the effects of renal failure. In: Textbook of Nephrology: 8.42-8.62, edited by Massry SG and Glassock RJ; Williams and Wilkins, Baltimore/London

Doyle AE (1985) Calcium antagonists. In: Calcium and calcium-antagonists in hypertension. Proceedings of the Satellite Symposium to the 2nd European Meeting on Hypertension, Milan. in press

Engelhard D, Stutman HR, Marks MI (1984) Interaction of ketoconazole with rifampicin and isoniazid. New Engl J of Med 311: 1681-1683

Evans GH, Shand DG (1973) Disposition of Propranollol VI. Clin Pharmacol Ther 14: 494-500

Feely J, Wilkinson G, Wood A (1981) Reduction of liver blood flow and propranolol metabolism by cimetidine. New Engl J of Med 304: 692-695

Fellenius E (1983) Muscle fatigue and beta-blockers - A review. Int J Sports Med 4:1-8

Fleckenstein A (1971) Specific inhibitors and promoters of calcium action in the excitationcontraction coupling of heart muscle and their role in the production or prewention of myocardial lesions. In: Calcium and the Heart: 135-188 Edited by Harris P, Opie L, Acadenic Press, New York

Hass H, Haerffelder $\mathrm{G}$ (1962) $\alpha$-Isopropyl- $\alpha[(\mathrm{N}-m e$ thyl-N-homoveratryl)- $\gamma$-amino-propyl]-, 3,4-dimethoxyphenylacetonitril, eine Substanz mit coronargefaesserweitemden Eigenschaften. Arneimittel-Forschung 12:549-558.

Hamann SR, Blowin RA, McAllister JP RG (1984) Clinical pharmacokinetics of verapamil. Clinical Pharmacokinetics $9: 26-41$

Kates RE (1983) Calciun antagonists: pharmacokinetic properties. Drugs 25: 113 124

Keefe DL, Yin-Gail Yee, Kates RE (1981) Verapamil protein binding in patients and in normal subjects. Clin Pharmacol Ther 29:21-26

Lund-Johansen $\mathrm{P}$ (1984) Hemodynamic effects of verapamil in essential hypertension at rest and during exercise. Acta Medica Scand Suppl 681: 109-115 
Maher JF (1984) Pharmacokinetics in patients with renal failure. Chin Neplarol 21, 3946

Nayler WG, Horowitz JD (1983) Calcium antagonists: a new class of drugs. Pharnacology Therapeutics $20: 203-262$

Patterson SE, Cohn VH (1984) Hepatic drug metabolism in rats with expermental chrontc renal failure. Biochemical Pharmacology 33: $711-716$

Rahn KH, Mooy J, Boehm R, w.d. Vet A (1985) Reduction of bioavallability of verapamil by rifampicin. New Engl J of Med 312: 920-921

Reidenberg MM (1977) The biotransformation of drugs in renal failure. Am J of Med 62 : 482485

Rowell LB, Blackmon JR, Bruce RA (1964) Indocyanine green clearance and estimated hepatic blood llow during mild to maximal exercise in upright man. J Clin Invest 43: 1677-1690

Sedman AJ (1984) Cimetidine - drug interactions. Am J of Med 76: 109-114.

Singh $B N$, Ellrodt $G$ (1978) Verapamil: A rewiew of its pharmacological properties and therapentic use. Drugs 15: 169-197

Smith MS, Benyunes MC, Bjornsson TD, Shand DG, Pritchet ELC (1984) Influence of cimetidine on verapamill kinetics and dynamics. Clin Pharmacol Ther 36: 551-554

Swartz RD, Sidell FR, Cucinell SA (1974) Effects of physical stress on the disposition of drugs eliminated by the liver in man. J of Pharm and Exper Therapeutics 188: 1-7

Sweeney GD (1981) Drugs - some basic concepts. Med Sci Sports Exercise 13: 247-251

Wilkinson GR, Shand DG (1975) A physiological approach to hepatic drug clearance. Clin Pharmacol Ther 18: $377-390$

Wing LMH, Miners JO, Lillywhite $\mathrm{K}$, Harrington B (1983) Verapamil disposition - eflects of sulphinpyrazone and cimetidine. Abstracts II World Conference on Clinical Pharmacology and Therapeutics; Washington D.C. (USA) 


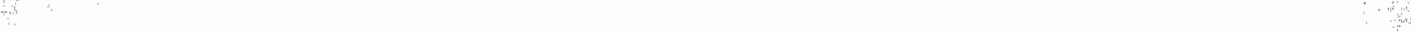




\section{Samenvatting}


Calcium antagonisten worden sinds een aantal jaren toegepast ter behandeling van hypertensie. Zij hebben een aantal eigenschappen die hen voor deze indicatie geschikt maken. Zij verminderen de contractie van de gladde spieren in de vaatwand en bewerkstelligen daardoor een daling van de perifere weerstand die in het algemeen verhoogd is bij essentiele hypertensie. Daarbij veroorzaken zij in tegenstelling tot andere vaatverwijders geen of veel minder vocht-en zoutretentie, en zijn orthostatische klachten zeldzaam. De oudste representant van deze groep geneesmiddelen, verapamil, heeft daarbij nog het voordeel dat het nauwelijks reflectoire sympathicus activiteit opwekt. Voor bepaalde groepen van hypertensie patienten worden daarom calcium antagonisten en in het bijzonder verapamil als middel van eerste keuze genoemd. Hoewel er reeds veel over verapamil is onderzocht, is over een aantal aspecten van de toepassing van dit middel bij hypertensie minder bekend.

\section{Farmacokinetiek van verapamil bij nierinsufficientie (hoofdstuk 2)}

Bij niersufficientie komt frequent hypertensie voor. Daarom zal het vaak wenselijk zijn sommige patienten met nierinsufficientie te behandelen met verapamil. Hoewel verapamil grotendeels door de lever wordt afgebroken, is het toch mogelijk dat de farmacokinetiek van dit middel door uremie wordt beinvloed. Door andere onderzoekers was reeds vastgesteld dat de eitwitbinding van verapamil door uremie niet verandert.

Wij onderzochten de farmacokinetiek van verapamil na toediening van een enkele intraveneuze dosis, na een enkele orale dosis, en na een orale toediening gedurende 5 dagen. Er werden ten opzichte van een groep van controle personen geen verschillen geconstateerd in de halfwaardetijd, de totale lichaamsklaring, de biologische beschikbaarheid, en het verdelingsvolume. De hoevelheid die door een kunstnier werd uitgescheiden, was zeer klein in vergelijking met de totale lichaamsklaring. Daarom kan worden geconcludeerd clat de dosering van verapamil niet hoeft te worden aangepast bij ernstige nierinsufficientie en tijdens haemodiallyse.

2. Geneesmiddeleninteracties met verapamil (hoofdstuk 3)

Verapamil wordt grotendeels door de lever gemetaboliseerd. Factoren die het levermetabolisme beinvloeden, kunnen daarom ook de farmacokinetiek van verapamil veranderen. Bepaalde medicamenten hebben een invloed op het levermetabolisme. Van cimetidine is het bekend dat het de leverenzymen 
remt, terwijl rifampicine een sterke stimulator hiervan is. Daarom onderzochten wij de invloed van deze middelen op de farmacokinetiek van verapamil. Hierbij bleek dat cimetidine geen invloed had op de kinetiek van oraal toegediend verapamil. In de literatuur zijn hierover tegenstrijdige publicaties verschenen. Op grond van onze studie en de literatuur gegevens kan echter worden geconcludeerd dat cimetidine in de normale dosering de farmacokinetiek van oraal verapamil niet beinvloedt.

Daarentegen hadden tuberculostatica, waaronder rifampicine, een grote invloed op de kinetiek van oraal verapamil, en wel veroorzaakten zij een sterke reductie van de biologische beschikbaarheid. Dit effect was ook aanwezig met een monotherapie van rifampicine, en verdween na het staken van dit middel. Deze bevinding suggereert dat de lage bloedspiegels van verapamil tijdens het gebruik van de tuberculostatica een gevolg zijn van het gebruik van rifampicine. Het effect van rifampicine en andere tuberculostatica op de kinetiek van intraveneus toegediend verapamil was veel minder duidelijk dan na orale toediening, hetgeen verklaarbaar is bij een geneesmiddel met een hoog 'firstpass effect" door de lever. Uit deze studie kan worden geconcludeerd dat oraal verapamil bij patienten die tevens rifampicine gebruiken, in een hogere dosering dan normaal moet worden toegediend om therapeutische bloedspiegels te verkrijgen.

\section{De invloed van inspanning op de farmacokinetiek van verapamil (hoofdstuk 4).}

De meeste farmacokinetische studies met verapamil zijn uitgevoerd in rust. Echter, veel patienten verrichten dagelijks ook regelmatig lichamelijke inspanning. Lichamelijke inspanning kan de kinetiek van geneesmiddelen op verschillende wijze beinvloeden. Door lichamelijke oefening wordt de lever-en darmdoorbloeding verminderd, en hierdoor neemt de resorptie en het levermetabolisme af. Ook kan de eiwitbinding en het verdelingsvolume worden veranderd. Over de invloed van inspanning op de kinetiek van geneesmiddelen is weinig bekend. Onlangs is een studie gepubliceerd over het effect van lichamelijke inspanning op de kinetiek van propranolol. Daarbij werd verrassenderwijs een verminderde halfwaardetijd en biologische beschikbaarheid van dit middel gevonden tijdens inspanning. In onze studie werd echter geen verschil gevonden in de farmacokinetiek van verapamil in rust en tijdens submaximale inspanning. Daarom kan worden geconcludeerd dat normale lichamelijke inspanning de kinetiek van verapamil, in tegenstelling tot die van propranolol, niet beinvloedt. 
4. Een vergelijking van de invloed van propranolol en verapamil op de submaximale inspanningstolerantíe bij patienten met essentiele hypertensie (hoofdstuk 5).

Reeds lang is het bekend dat beta-blokkers vermoeidheidsklachten veroorzaken en de maximale inspanningstolerantie verminderen. Submaximale inspanning is waarschijnlijk een betere test om de inspanningstolerantie te beoordelen daar het meer gelijkt op de dagelijkse lichamelijke activiteiten. Wij onderzochten nu bij een zelfde groep van patienten met essentiele hypertensie de invloed van propranolol en verapamil op de tolerantie bij submaximale inspanning, en vergeleken die met elkaar en met placebo. De dosering van propranolol en verapamil werd zodanig vastgesteld dat beide een zelfde bloeddrukdaling veroorzaakten bij de verschillende patienten. Propranolol veroorzaakte een duidelijke vermindering van de volhoudtijd tijdens submaximale inspanning in vergelijking met placebo, terwijl tijdens verapamil geen significant verschil werd gezien. Deze bevinding kan van belang zijn woor hypertensie patienten met klachten van vermoeidheid tijdens het gebruik van betablokkers. Voor deze patienten kan verapamil wellicht een goed alternatief bieden. 



\section{Curriculum vitae}

The author of this thesis was born on December 25, 1941 in Gramsbergen, The Netherlands.

He graduated from the Christelijk Gymnasium, Utrecht in 1960. He studied at the Rijksuniversiteit in Utrecht and graduated in 1968. After military service, he started his residency in Internal Medicine at the Department of Internal Medicine of the Elisabeth Gasthuis in Haarlem (Head: Dr. L. van Beugen). In 1972 he continued his training in internal medicine at the Department of Internal Medicine I of the Erasmus University Rotterdam (Head: Prof. Dr. J. Gerbrandy).

After registration as internist in 1975 he continued his work at this department in the Division of Nephrology, Haemodialysis and Kidney Transplantation (Head: Prof. Dr. L.D.F. Lameyer).

Since 1979, he is a staff member of the Department of Internal Medicine, St. Annadal Hospital, Maastricht, since January 1, 1986: Academic Hospital Maastricht (Head - till 1982 - : Dr. J.M. Coenegracht. Since 1982: Prof. Dr. J.A. Flendrig). As a nephrologist he is in charge of the haemodialysis unit. At the same time, he is a member of the Department of Medicine, University of Limburg Medical School, Maastricht. 
?. 


\section{Dankwoord}

Het is mij een grote eer mijn promotor te mogen bedanken, Professor Heinz Rahn. In de afgelopen jaren heb ik veel geleerd, en wel in het bijzonder - als ik één voorbeeld mag noemen - tijdens de verschillende congressen die door mij de laatste jaren bezocht zijn. Hiervoor zal ik je zeer erkentelijk blijven. Het was mij een groot genoegen in de groep Klinische Farmakologie te mogen werken.

Mijn co-promotor, Professor Harry Struyker Boudier, dank ik in het bijzonder voor de zeer stimulerende belangstelling die hij altijd voor dit onderzoek en de resultaten heeft getoond.

Ook dank ik je voor de zeer nauwgezette wijze waarop je het manuscript hebt beoordeeld.

I am gratefully acknowledged to Professor Bock for the critical review of the manuscript.

Professor Gribnau en Professor Wellens dank ik ten zeerste dat zij bereid waren als referent op te treden, en voor hun kritische beoordeling van het manuscript.

Graarne dank ik hierbij Professor Guus Flendrig, hoofd van de Interne Afdeling, dat hij mij de gelegenheid heeft geboden dit onderwerp in zijn kliniek te bewerken.

Het is mij een eer hier te mogen noemen Dr. Marleen van Baak, die bij het opzetten van verschillende studies onschatbare diensten heeft bewezen.

Bij het opstarten van dit onderzoek is Michiel Schols zeer belangrijk geweest. Marlies van Hooff en Roland Böhm hebben bij de verschillende onderzoekingen enorm veel geholpen!

Voor de laboratoriumbepalingen dank ik ten zeerste Beate Arends, Judith van Kemenade, Riet Daemen en Monique Fuss. Monique Fuss maakte bovendien de tekeningen in de hoofdstukken 2,3 en 5.

Van onschatbare waarde is Anke Wijnands geweest die met onuitputtelijk geduld en incasseringsvermogen de verschillende versies van het manuscript heeft uitgetyped.

Tenslotte dank ik alle proefpersonen die aan deze studie hun medewerking hebben verleend, en die daarvoor veel vrije tijd hebben moeten opolferen. Hiervoor mijn zeer hartelijke dank! 